\title{
Wolbachia: endosymbiont of onchocercid nematodes and their vectors
}

\author{
Ranju Ravindran Santhakumari Manoj ${ }^{1}$, Maria Stefania Latrofa' ${ }^{1}$, Sara Epis ${ }^{2}$ and Domenico Otranto ${ }^{1,3^{*}(0)}$
}

\begin{abstract}
Background: Wolbachia is an obligate intracellular maternally transmitted, gram-negative bacterium which forms a spectrum of endosymbiotic relationships from parasitism to obligatory mutualism in a wide range of arthropods and onchocercid nematodes, respectively. In arthropods Wolbachia produces reproductive manipulations such as male killing, feminization, parthenogenesis and cytoplasmic incompatibility for its propagation and provides an additional fitness benefit for the host to protect against pathogens, whilst in onchocercid nematodes, apart from the mutual metabolic dependence, this bacterium is involved in moulting, embryogenesis, growth and survival of the host.

Methods: This review details the molecular data of Wolbachia and its effect on host biology, immunity, ecology and evolution, reproduction, endosymbiont-based treatment and control strategies exploited for filariasis. Relevant peerreviewed scientic papers available in various authenticated scientific data bases were considered while writing the review.
\end{abstract}

Conclusions: The information presented provides an overview on Wolbachia biology and its use in the control and/ or treatment of vectors, onchocercid nematodes and viral diseases of medical and veterinary importance. This offers the development of new approaches for the control of a variety of vector-borne diseases.

Keywords: Wolbachia, Endosymbionts, Onchocercid nematodes, Vector, Treatment, Control

\section{Background}

Endosymbiosis is an intimate form of symbiotic association in which one organism dwells within the body of another, forming a spectrum of relationships from parasitism to obligatory mutualism [1]. Many obligate mutual symbiotic associations are based on metabolic complementation and strengthen or increment the biochemical versatility and pathways of one or both hosts $[2,3]$. Wolbachia is a striking example of this mechanism in both onchocercid nematodes and arthropod vectors [4]. Though many endosymbionts have been observed in arthropod and nematode hosts, Wolbachia is the one which is most widely distributed and explored [4]. Like the mitochondria organelle, this obligate intracellular

\footnotetext{
*Correspondence: domenico.otranto@uniba.it

${ }^{1}$ Department of Veterinary Medicine, University of Bari, Valenzano, Italy

Full list of author information is available at the end of the article
}

gram-negative bacterium is also transmitted through the host germ line to the next generation [5]. After the initial discovery in the reproductive organs of Culex pipiens mosquito by M. Hertig and S. B. Wolbach in 1924 [6], the description of this bacterium took another 12 more years [7]. In the late 1960s and early 1970s, ultrastructural studies on filarial nematodes revealed the presence of unusual intracellular bodies in the oocyte hypodermis of these worms, which were interpreted as bacteria [8-10] and later identified as Wolbachia by Sironi and colleagues [11]. Currently, this endosymbiont has been reported in around 50\% of terrestrial arthropod species (i.e. insects, mites, crustaceans, spiders, scorpions, collembolans) and in several species of onchocercid nematodes [12, 13]. Similarly, this bacterium has also been identified in non-filarial plant nematodes, Radopholus similis [14] and Pratylenchus penetrans of the order Tylenchida [15]. In onchocercid nematodes, Wolbachia

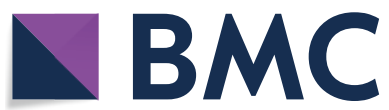

(c) The Author(s) 2021. This article is licensed under a Creative Commons Attribution 4.0 International License, which permits use, sharing, adaptation, distribution and reproduction in any medium or format, as long as you give appropriate credit to the original author(s) and the source, provide a link to the Creative Commons licence, and indicate if changes were made. The images or other third party material in this article are included in the article's Creative Commons licence, unless indicated otherwise in a credit line to the material. If material is not included in the article's Creative Commons licence and your intended use is not permitted by statutory regulation or exceeds the permitted use, you will need to obtain permission directly from the copyright holder. To view a copy of this licence, visit http://creativeco mmons.org/licenses/by/4.0/. The Creative Commons Public Domain Dedication waiver (http://creativecommons.org/publicdomain/ zero/1.0/) applies to the data made available in this article, unless otherwise stated in a credit line to the data. 
has a mutual association in which it is involved in embryogenesis, moulting, growth and survival [16] of the filariae, and it has been hypothesised that the worm provides essential aminoacids for bacterial growth [17]. However, in arthropods, the "parasitic side" of Wolbachia prevails, in that this bacterium manipulates the host reproduction to increase its own fitness and spread into the host population $[18,19]$. Reproductive manipulations exerted by Wolbachia on its hosts have extensively been investigated and include male killing, feminization, parthenogenesis and cytoplasmic incompatibility (CI) [4]. The effects of Wolbachia presence on its hosts (i.e. host biology, physiology, immunity, ecology, evolution and reproduction) have been exploited for the development of promising endosymbiont-based strategies for the treatment of filariasis and for the control of important vector-borne diseases of medical and veterinary relevance [4]. This review details Wolbachia's evolution, molecular identification, interaction with arthropods and nematodes and the development of endosymbiont-based treatment and control strategies.

\section{Evolutionary history of Wolbachia}

Wolbachia evolved and adapted to its intracellular lifestyle in the context of an evolutionary change that included other obligatory intracellular organisms (such as the ancestors of Rickettsia, Ehrlichia, Anaplasma and Midichloria) and extended over a hundred million years, starting from ancient alphaproteobacteria [20-22]. Wolbachia has a small genome $(0.8-1.7 \mathrm{Mbp})$ with large segments of mobile and repetitive DNA, which is uncommon in vertically transmitted (generally from mother to offspring) organisms [4, 23]. Despite the erosive genomic processes due to host restriction and acquisition maintenance, these repetitive host DNA sequences are supposed to play a major role in the evolution of Wolbachia [24]. Balance among vertical transmission, host switching, recombination insertion sequences and bacteriophage sequences helps in the adaptation and global distribution of Wolbachia [4, 22]. Based on their main genetic evolution in a large variety of hosts, Wolbachia have been classified in 17 supergroups, designated by the letters $\mathrm{A}$ to $\mathrm{S}[23,25,26]$. Exceptions are represented by supergroup G, which was lately been withdrawn because of the high probability of being the result of a genetic recombination event [27, 28], and supergroup $R$ from cave spiders [29], which showed a strong association with Wolbachia strains of supergroup A, based on genetic distance measures and phylogenetic analyses [30]. Overall, Wolbachia of arthropods is categorised in supergroups A, B, E, H, I, K, that of nematodes in C, D, J [31] and supergroup $\mathrm{L}$ only in plant-parasitic nematodes [15]. Supergroup F is an exception which is common in many arthropod species such as termites, spiders, mites [32], bugs (i.e. Cimex lectularius and Montina sp.) [33] and in human filariae (i.e. Mansonella) [34-36], filariae of black bear, (Cercopithifilaria japonica) [12] and that of geckoes (Madathamugadia hiepei) [37]. Currently, a complete genome of Wolbachia from the supergroup $\mathrm{F}$ is available from the $w$ Cle strain of C. lectularius [2] and $w$ Mhie strain of M. hiepei [23].

In particular, supergroups A and B are the most represented among arthropods and it is estimated that the common ancestor of both would have diverged approximately 58-67 million years ago. Though estimation of the origin of Wolbachia is a controversial topic and a suitable outgroup for phylogenetic analysis of Wolbachia is unavailable, it has been suggested that arthropod and onchocercid nematode supergroups diverged around 100 million years ago (i.e. 500 million years after their host) [38, 39]. It is important to note that these estimations were based on small samplings. The presence of Wolbachia in phylogenetically distant hosts such as nematodes and arthropods suggests that these endosymbionts experienced some type of horizontal transmission during their ancient evolution. For example, a horizontal transfer of Wolbachia could have occurred from one host phylum to the other; alternatively, one of the two phyla could have acquired Wolbachia from a third party [39]. Incongruence in phylogenies of Wolbachia and their arthropod hosts (e.g. the unnatural occurrence of identical Wolbachia strains in distantly related species) can also be explained by the horizontal transmission of these endosymbionts [38, 40, 41]. In addition, ecological events occurring in the transmission and global distribution of this bacterium in arthropods include the relationship between and amongst hosts, such as in the case of parasitism, phoresis [42], predation and cannibalism [43], blood contact after injury [44], presence in parasitoids [45] or just sharing of common food substrates [46].

Unlike arthropods, phylogenetic congruence of nematodes with Wolbachia indicates an obligatory dependent relationship with the organism, followed by host-parasite co-evolution and vertical transmission via infected females [34, 39]. Though the association between Wolbachia and nematodes has been hypothesised to have been acquired as a single event [34, 39], recent genome analyses suggest multiple events of acquisition of $\mathrm{Wol}$ bachia with local coevolutionary patterns in different major lineages and wider presence of transposable elements in supergroup D (i.e. in Wolbachia from the Onchocerca genus) [13, 23]. Moreover, different patterns of symbiosis among various filarial nematodes may be due to multiple acquisitions of the bacteria and/ or selective pressures imposed on it [23]. The strongest coevolution pattern has been observed in Onchocerca 
spp. especially in Onchocerca lupi, Onchocerca gutturosa, Onchocerca lienalis, Onchocerca volvulus and Onchocerca ochengi, strongly supported by global fit analyses [13]. Furthermore, the detection of Wolbachia-like gene transcript in Onchocerca fluxosa, which in turn is the only known Onchocerca species devoid of Wolbachia, suggests the ancestral presence of this symbiont in this nematode [47, 48]. Accordingly, the absence of Wolbachia in anuran onchocercid nematodes indicates that they would have diversified before the first bacterial invasion in onchocercid lineage (i.e. around 110 million years ago) $[25,39,49]$. However, the presence of supergroup $\mathrm{F}$ in both insects and filariae of humans, black bear and geckoes makes understanding of the whole picture even more complicated.

\section{Molecular detection and identification of Wolbachia}

Though the genus Wolbachia has a relatively small genome (i.e. $0.8-1.7 \mathrm{Mbp}$ ) it encompasses large phylogenetic variations [23, 39]. Amongst target genes, $16 \mathrm{~S}$ rRNA showed a nucleotide divergence from $0.2 \%$ to $2.6 \%$ [50] but provided limited information for inferring phylogenetic relationships [50]. Hence, the genetic characterisation using $16 \mathrm{~S}$ rRNA is complemented by a set of housekeeping genes (e.g. FtsZ, groEL, gltA and $\operatorname{cox} A$ ) mainly for the phylogenetic analysis [31] (Table 1). Wolbachia surface protein $(w s p)$ gene, ten times more variable than $16 \mathrm{~S}$ rRNA and FtsZ, is employed to identify different groups and strains of Wolbachia $[51,52]$ but not for large-scale phylogenetic analysis since it is affected by recombination amongst supergroups [28]. Moreover, $g r o E$ is also used for strain differentiation because of the faster evolution rate of non-coding regions that separate the coding heat shock protein (HSP) genes (i.e. groES and groEL) [53]. Therefore, PCR coupled sequencing of a combination of genes should be employed to assess the group relationships in Wolbachia [54]. It has been estimated that multiple infections can be detected by techniques such as quantitative PCR with highly specific primers $[55,56]$, cloning and sequencing [57], and southern hybridization [58]. Similarly, loop-mediated isothermal amplification (LAMP) is used in resource-limited laboratories for the simultaneous detection of more than one strain of Wolbachia [59]. A metagenomics-based approach can be employed to provide whole-genome sequence information for all associated endosymbionts of a nematode or an arthropod vector [60-63].

To date, eight complete genomes (i.e. $w \mathrm{Bm}$ of Brugia malayi, wBp of Brugia pahangi, wOo of Onchocerca ochengi, wOv of Onchocerca volvulus, $w$ Dimm, Dirofilaria immitis, $w$ Ctub of Cruorifilaria tuberocauda, wDcau of Dipetalonema caudispina, $w$ Lsig of
Litomosoides sigmodontis) and three draft genomes of Wolbachia from filarial nematodes have been published (i.e. wLbra of Litomosoides brasiliensis, $w \mathrm{~Wb}$ of Wuchereria bancrofti and wMhie of Madathamugadia hiepei) [17, 23, 64-67]. Of the 36 complete genomes and 55 draft genomes of Wolbachia available, $84 \%$ belong to supergroups A and B [23]. Advanced genome analyses on Wolbachia suggest that supergroups A and B were originated by genetic isolation events rather than convergent evolution [68]. As per genome analyses, the relationship between onchocercid nematodes and Wolbachia may represent a "genetic addiction" rather than mutualism [1]. Compared to arthropods, the filarial nematode genome has smaller size (i.e. 863,427 bp for $w$ Dcau versus $1,267,782$ bp for $w$ Mel from Drosophila melanogaster or 1,801,626 bp for $w$ Fol from Folsomia candida), presence of fewer transposable elements as insertion sequence elements (ISs) and group II intron-associated genes, prophage-related genes and repeat-motif proteins as ankyrin domains [23]. Data analyses on intragenomic recombinations, transposable elements, chromosome rearrangements, mutational bias and gene loss or gain on different supergroups revealed that supergroup $C$ strains have a very low number of genomic rearrangements, paucity of insertion sequence elements and strong GC asymmetric distribution, which is considered to be due to the long-term obligate symbiotic relationship with their host [69]. Further addition of the genome of new Wolbachia strains from different filarial nematodes will help to do detailed analyses and to have a clear picture on the divergent symbiotic mechanisms and the evolutionary pattern of this bacterium.

\section{Wolbachia in onchocercid nematode vectors}

First reported in Cx. pipiens [7], Wolbachia is a widespread endosymbiont among arthropods with an estimated prevalence ranging from 20 to around $75 \%$, according to different studies [38, 70]. Indeed, arthropods have been found to be infected with single (e.g. $C$. lectularius) or multiple Wolbachia variants (e.g. Drosophila simulans, $C x$. pipiens) in the same species or even in the same insect individuals (i.e. superinfection) [71-74] (Table 2). Unlike onchocercid nematodes, arthropodWolbachia association is more parasitic, in that the bacteria obtain fitness advantage by the reproductive manipulations of the host [16, 75-77]. Apart from these, the bacterium is involved in iron homeostasis of the host and confers immunity to viral/onchocercid nematode infections, thereby reducing the vector capacity of their hosts [78-80]. This has been demonstrated in Aedes aegypti infected by Wolbachia popcorn strain (wMelPop) wherein the symbiosis conferred protection to the mosquitoes against onchocercid nematodes and Plasmodium 
Table 1 Molecular approaches for the detection of Wolbachia in vectors and onchocercid nematodes

\begin{tabular}{|c|c|c|c|c|}
\hline Primer name & Gene targeted & Type of PCR & Product size & References \\
\hline $99 F, 99 R$ & $16 \mathrm{~S}$ rRNA & $C P C R$ & 895 & {$[50,164]$} \\
\hline Wspecf, Wspecr & $16 \mathrm{~S}$ rRNA & $\mathrm{CPCR}$ & 438 & {$[165]$} \\
\hline 16SWolbf, 16SWolbr & $16 \mathrm{~S}$ rRNA & $C P C R$ & 1014 & {$[34]$} \\
\hline INTF1, INTR & $16 \mathrm{~S}$ rRNA & $C P C R$ & 130 & {$[166]$} \\
\hline INTF2, INTR2 & $16 \mathrm{~S}$ rRNA & $C P C R$ & 136 & {$[166]$} \\
\hline 553F_W, 1334R_W & $16 \mathrm{~S}$ rRNA & $\mathrm{CPCR}$ & 781 & {$[54]$} \\
\hline WolbF, Wspecr & $16 \mathrm{~S}$ rRNA & $\mathrm{CPCR}$ & & [167] \\
\hline $63 f, 1387 R, 76 f, 1012 R$ & $16 \mathrm{~S}$ rRNA & Nested PCR & 852 & {$[168]$} \\
\hline WN16S-F, WN16S-R & $16 \mathrm{~S}$ rRNA & qPCR & & [169] \\
\hline W-Specf, W-Specr, & $16 \mathrm{~S}$ rRNA & qPCR & 438 & [170] \\
\hline W-Specf, W16S & & & 102 & \\
\hline WSPintF, WSPintR & $w s p$ & $\mathrm{CPCR}$ & 576 & {$[34,114,168]$} \\
\hline $81 F, 691 R$ & $w s p$ & $C P C R$ & 610 & {$[51,171]$} \\
\hline $136 \mathrm{~F}, 691 \mathrm{R}$ & wsp (Group A) & & 556 & \\
\hline $308 \mathrm{~F}, 691 \mathrm{R}$ & wsp (Subgroup Mel) & & 405 & \\
\hline $328 \mathrm{~F}, 691 \mathrm{R}$ & wsp (Subgroup AlbA) & & 379 & \\
\hline $173 F, 691 R$ & wsp (Subgroup Mel and AlbA) & & 541 & \\
\hline $181 \mathrm{~F}, 691 \mathrm{R}$ & wsp (Subgroup wPap) & & 506 & \\
\hline $165 \mathrm{~F}, 691 \mathrm{R}$ & wsp (Subgroup wAus) & & 506 & \\
\hline $81 F, 531 R$ & wsp (Subgroup wPap and wAus) & & 460 & \\
\hline $81 F, 522 R$ & wsp (Group B) & & 442 & \\
\hline $183 \mathrm{~F}, 691 \mathrm{R}$ & wsp (Subgroup Pip) & & 501 & \\
\hline$w s p F, w s p R, g r F, g r R$ & $w s p$ & qPCR & & {$[172]$} \\
\hline wspTMF, wspTMR & $w s p$ & qPCR & & [59] \\
\hline WSP.F3, WSP.B3, WSP.FIP, WSP.BIP & $w s p$ & LAMP assay & & [173] \\
\hline FIP_wMel/wPop & wsp (wMel/ wPop) & LAMP assay & & {$[59]$} \\
\hline \multicolumn{5}{|l|}{ BIP_wMel/wPop } \\
\hline \multicolumn{5}{|l|}{ F3_wMel/wPop } \\
\hline \multicolumn{5}{|l|}{ B3_wMel/wPop } \\
\hline \multicolumn{5}{|l|}{ LpF_wMel/wPop } \\
\hline \multicolumn{5}{|l|}{ LpB_wMel/wPop } \\
\hline $\mathrm{ftsZ} F$ F1, ftsZ_R1 & FtsZ & $C P C R$ & 524 & {$[40]$} \\
\hline FtsZUniF, FtsZUniR & FtsZ & $C P C R$ & & {$[174]$} \\
\hline $\mathrm{fts} Z \mathrm{fl}, \mathrm{fts} Z \mathrm{rl}$ & FtsZ & $\mathrm{CPCR}$ & $1043-1055$ & {$[38]$} \\
\hline Wol1F, Wol1R, Wol7F, Wol7R & FtsZ & Nested PCR & 147 & {$[175]$} \\
\hline MLST primers & $\begin{array}{l}16 \text { s rRNA, gatB, FtsZ, hcpA, fbpA } \\
\text { coxA. wsp }\end{array}$ & MLST & & {$[40]$} \\
\hline $\mathrm{ftsZ} 291, \mathrm{fts} Z 477$ & FtsZ & qPCR & & {$[176]$} \\
\hline WSP 420, WSP 583 & $w s p$ & & & \\
\hline Bm-wFtsZ-F, BmwFtsZ-R & FtsZ & qPCR & & {$[96]$} \\
\hline groEL-F, groEL-R & groEL & $\mathrm{CPCR}$ & & {$[32]$} \\
\hline WgroF1, WgroRev1 & groEL & $C P C R$ & 873 & {$[35]$} \\
\hline WgltAF1, WgltARev1 & Citrate synthase ( $g / t A)$ & $C P C R$ & 627 & {$[35]$} \\
\hline FbpA_F1, FbpA_R1 & FbpA & $C P C R$ & 509 & {$[40]$} \\
\hline hcpA_F1, hcpA_R1 & HсpA & $C P C R$ & 516 & {$[40]$} \\
\hline COXA_F1, coxA_R1 & $\operatorname{cox} A$ & $C P C R$ & 487 & {$[40]$} \\
\hline COlintF, COlintR & $\mathrm{COl}$ & CPCR & 689 & [34] \\
\hline Wseq01F, Wseq02R & gatB & $C P C R$ & 471 & {$[31]$} \\
\hline
\end{tabular}




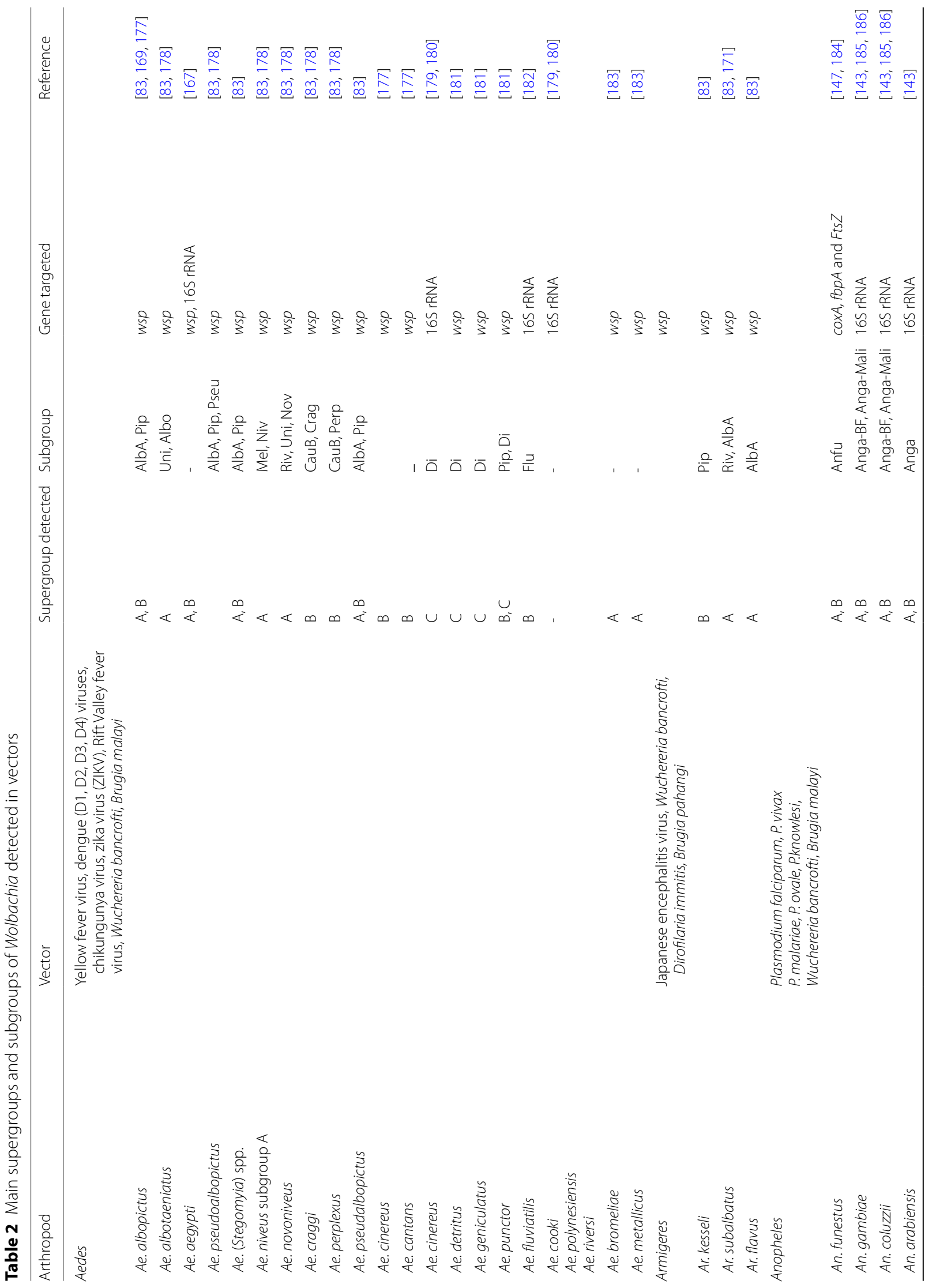




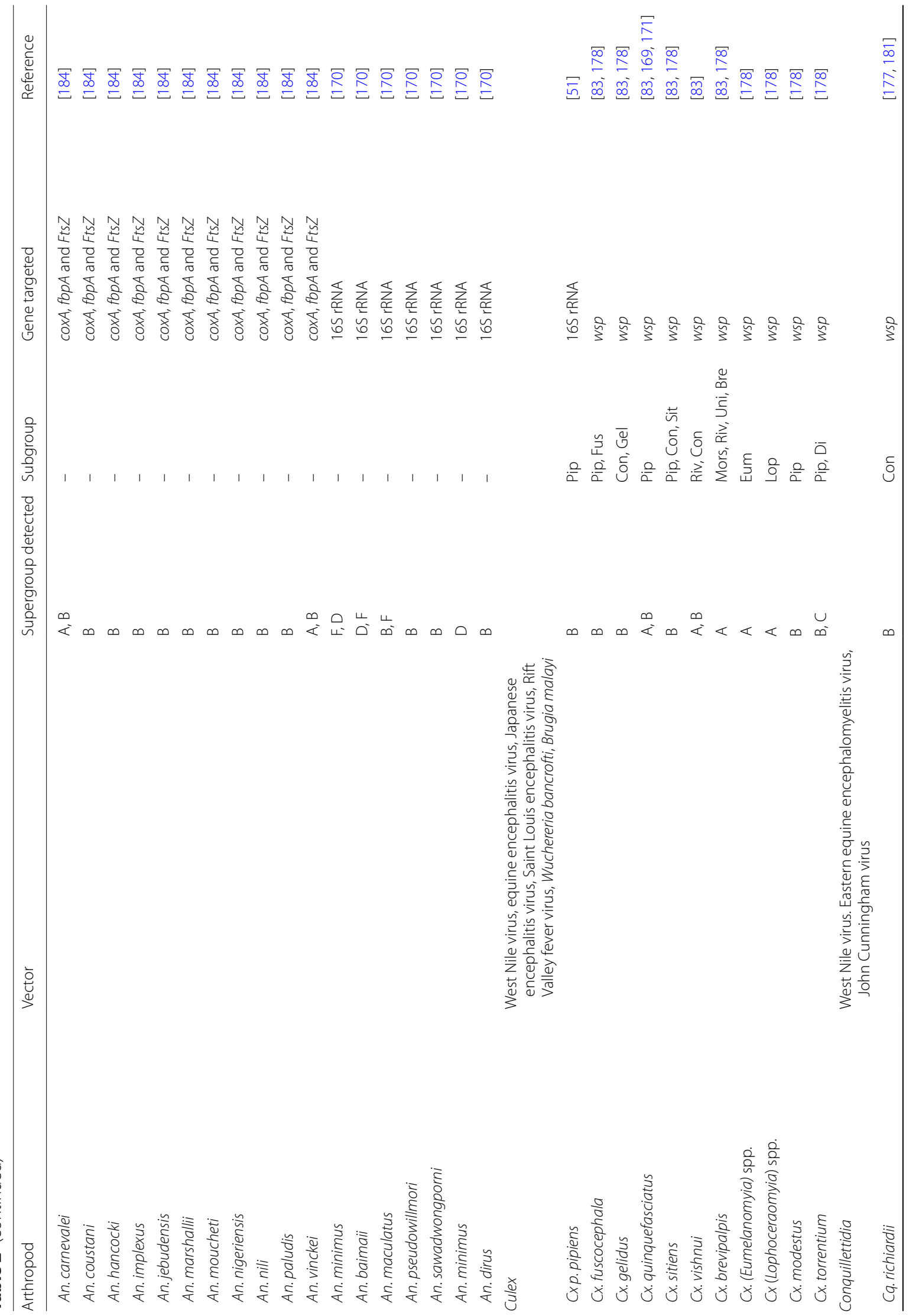




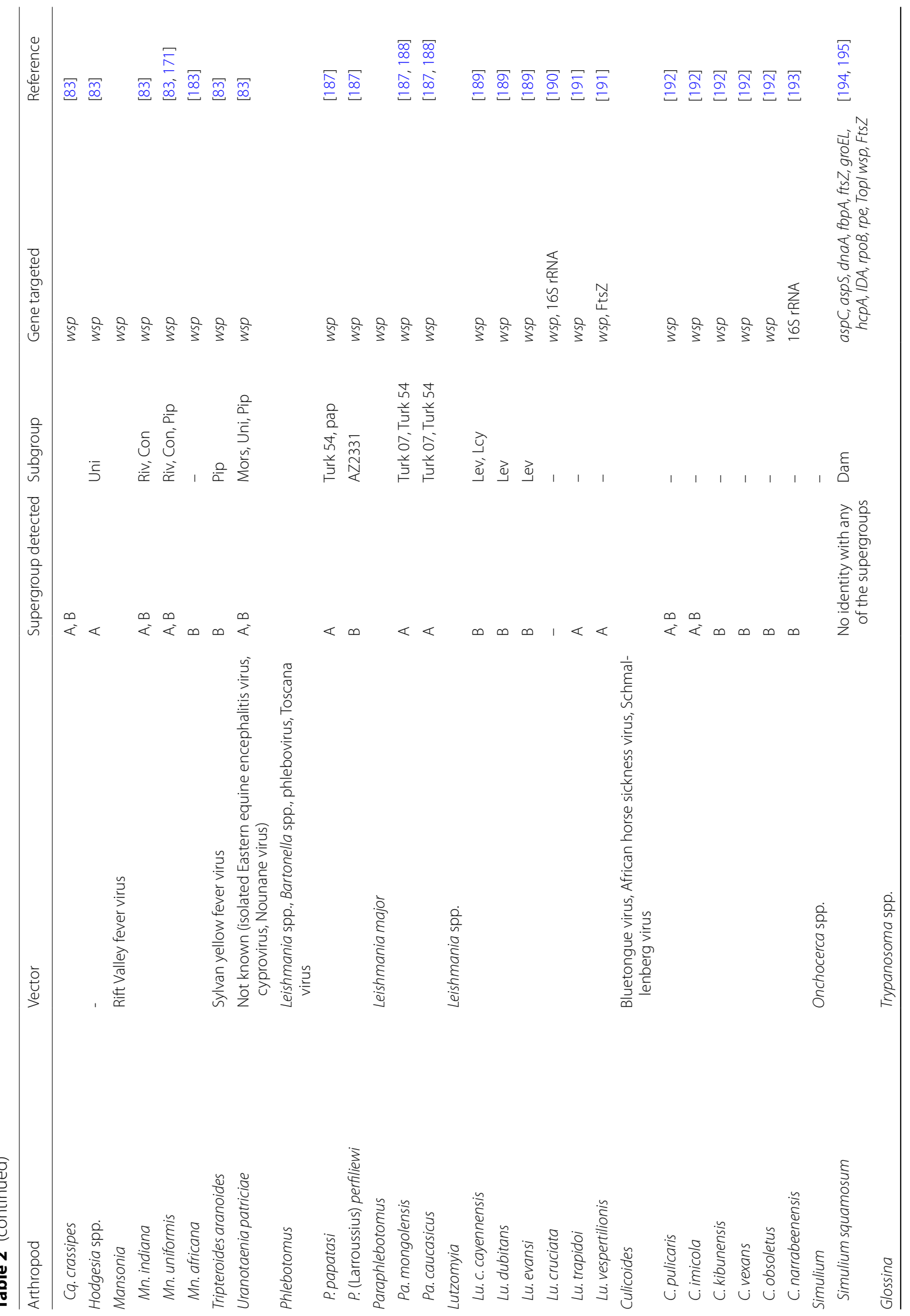




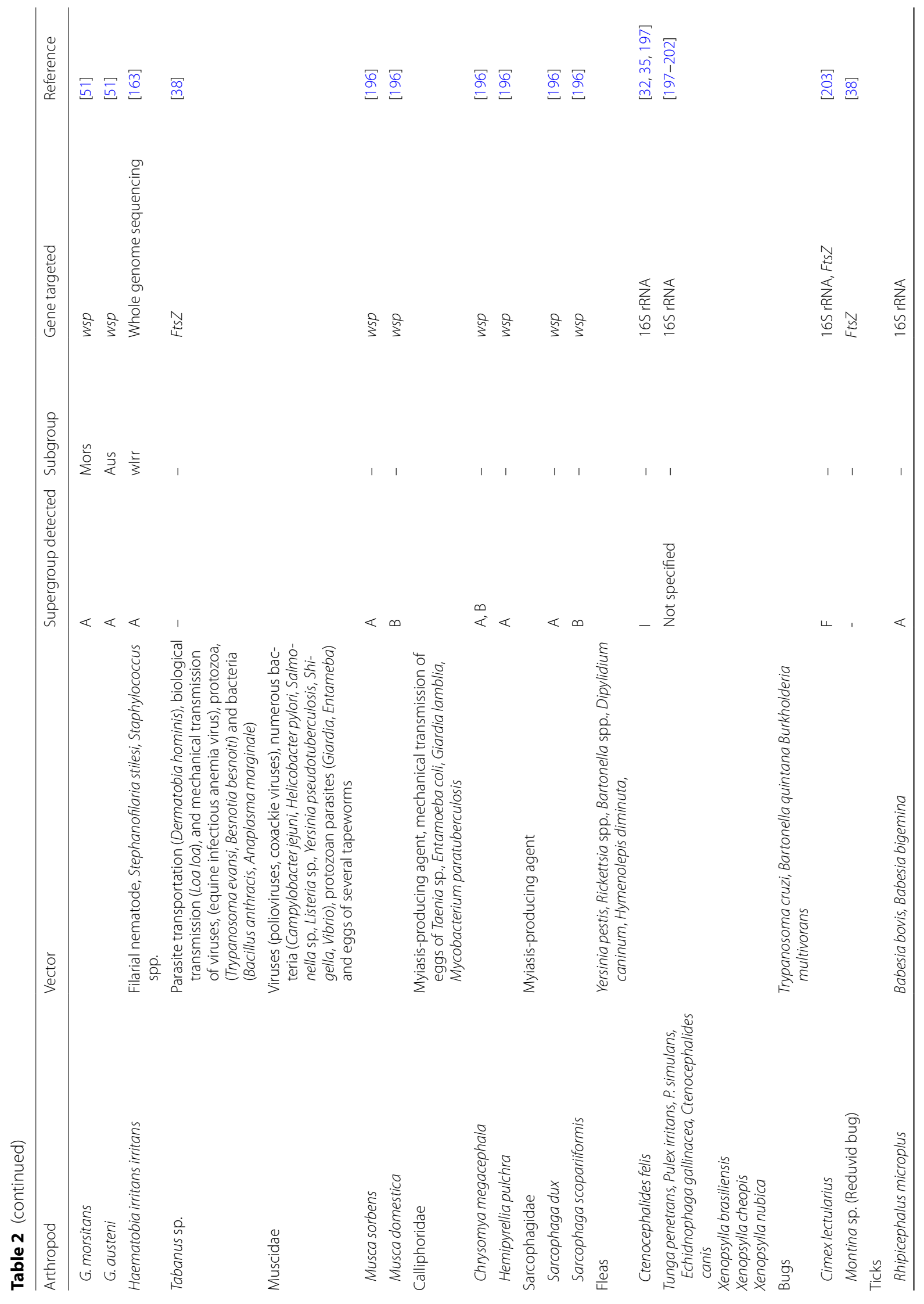




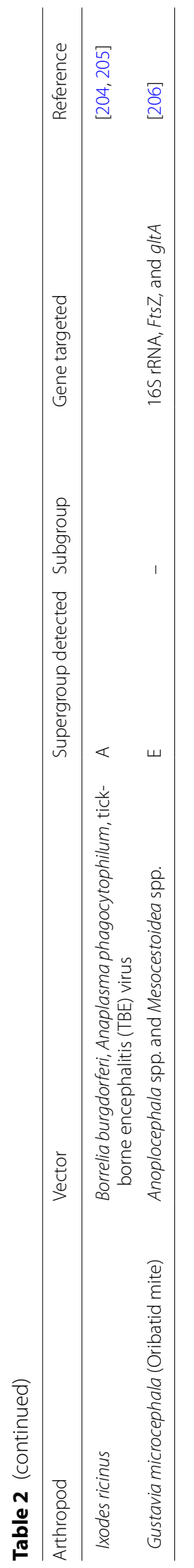


gallinaceum parasites $[79,81]$. The wide host range, tissue distribution and ability to perpetuate in insect populations render Wolbachia very attractive as a tool to reduce the vector potentiality of their host $[82,83]$ also thanks to its capability to determine reproductive manipulations (e.g. CI, parthenogenesis, male killing, feminization and meiotic drive) $[84,85]$. By these phenotypic alterations, the symbiont gives more reproductive advantage to infected over uninfected individuals or genders [63]; in general, Wolbachia is more beneficial for the individuals of the female sex, by virtue of the matriline vertical transmission [63]. In males, Wolbachia affects genes involved in sex differentiation and development by altering the DNA methylation whereas in females it might interfere with steroid hormone signalling [86]. In addition to this, Wolbachia wMelPop infection in Ae. aegypti mosquitoes produces hypomethylation/demethylation of genomic DNA, affecting 699 genes involved in apoptosis, defence response, phagocytosis, circadian rhythm, life span and locomotion behaviour [87-89]. The above changes may be capitalized as a mean for controlling vector-borne diseases [90] through life-shortening and increased locomotor activity and metabolism of mosquito vectors [90]. Overall, the above factors may indeed alter the mosquitopathogen relationship reducing the vectorial capacity of mosquitoes. In addition, the ability of Wolbachia to inhibit the replication of viral RNA can be used to suppress virus infection by transinfecting mosquitoes with proper Wolbachia strains $[78,91]$. Therefore, though the exact mechanism of such inhibition is not known, Wolbachia can be used as a biocontrol agent to effectively control viral pathogens such as dengue, yellow fever and chikungunya viruses and other vector-borne pathogens such as filarial nematodes and the malaria parasite, P. gallinaceum [92-94].

\section{Wolbachia in onchocercid nematodes}

Wolbachia are obligatory endosymbionts required for the reproduction, development and long-term survival of onchocercid nematodes [95] and it has been hypothesized that they get from them, in return, essential aminoacids [17]. This endosymbiont is present in gradually increasing density from L1 to the adult filarioid [16, 96] of three subfamilies of Onchocercidae (i.e. Onchocercinae, Dirofilariinae and Splendidofilariinae) and in 16 of the 26 genera examined [12, 13, 49, 97] (Table 3). Indeed, most species in Litomosoides or Onchocerca genera have been found infected with Wolbachia but only one in the genus Cercopithifilaria (i.e. Cercopithifilaria japonica) [49, 97, 98]. However, there is a huge diversity in the localisation of these bacteria in tissues of different onchocercid nematodes and even between male and female individuals within the same species $[97,99]$. In general, this bacterium is present in the female reproductive system and throughout embryonic development in the uterus of females (Fig. 1) being vertically transmitted to the progeny through the egg cytoplasm $[49,97,100]$. Other target tissues are the hypodemal lateral cords of the majority of onchocercid nematodes (e.g. Onchocerca, Brugia, Dirofilaria) and the intestinal cells of Mansonella (i.e. supergroup F) [12]. Nonetheless, the presence of Wolbachia may vary based on the species of onchocercid nematodes, being absent/less dense in lateral cords of Loxodontofilaria caprini [101] and Onchocerca dewittei japonica [97, 99]. Therefore, though the distribution of this endosymbiont is mostly concentrated in lateral cords and reproductive organs of the host, it exhibits different tropism to tissues during embryogenesis [12, 102]. In supergroups $C$ and $D$ there are similar patterns of embryonic segregation of Wolbachia with vertically transmitted bacteria reaching the lateral cords of the embryo by asymmetric mitotic segregation up to the ovaries [102, 103]. Though many investigations have focussed on the effects exerted by Wolbachia on the life performances of onchocercids, the role of this endosymbiont is still unclear $[75,102]$. Five biosynthetic pathways (e.g. heme, riboflavin, FAD, glutathione and nucleotide synthesis) are present only in Wolbachia but not in any other rickettsiales or in onchocercid nematode hosts [17] as some involved genes (e.g. heme-biosynthesis genes) are absent in the onchocercid genome $[64,104]$. In addition, the whole genome sequencing of Wolbachia from Brugia malayi $(w \mathrm{bm})$ gave some clues regarding the role played by this bacterium in the filarial life cycle [17]. For example, the presence of heme metabolism and/or riboflavin genes in the $w \mathrm{bm}$ genome suggested a role of this bacterium in iron metabolism of the onchocercid nematodes $[17,104]$ though the transport, degradation and regulation of heme within filarial parasites remain a mystery for the scientific community. Therefore, the inhibition of nematode moulting following an antibiotic therapy targeting Wolbachia has been linked to the lack of production of ecdisone-like hormones because of the absence of heme, involved in the biochemical paths above [17, 105]. Similarly, heme inhibitors interfered with the vitality of onchocercid nematodes [106]. Though heme and nucleotide biosynthetic pathways are more conserved in all Wolbachia genomes, pathways like vitamin B are more variable in onchocercid nematodes (e.g. the hypothesis of Wolbachia providing vitamin B7 is clear in some insects such as bedbugs or grasshoppers but not demonstrated in filarial nematodes) [23]. In addition, the absence of Wolbachia and of any other biosynthesis pathways in the genome of Loa loa $[107,108]$ might suggest the presence of other alternative pathways for the essential nutritional requirement for this onchocercid species, a still 
Table 3 Onchocercid nematodes, their hosts and location, vectors and the main supergroup of Wolbachia detected

\begin{tabular}{|c|c|c|c|c|c|}
\hline Onchocercids & Host & Location & Vector & $\begin{array}{l}\text { Wolbachia } \\
\text { supergroup }\end{array}$ & References \\
\hline Onchocercinae & & & & & [102] \\
\hline $\begin{array}{l}\text { Acanthocheilonema dracun- } \\
\text { culoides }\end{array}$ & Canids & $\begin{array}{l}\text { Coelomic cavity and subcuta- } \\
\text { neous tissue }\end{array}$ & $\begin{array}{l}\text { Hippobosca } \\
\text { Heterodoxus }\end{array}$ & NA & [102] \\
\hline $\begin{array}{l}\text { Acanthocheilonema recondi- } \\
\text { tum }\end{array}$ & Canids & Subcutaneous tissue & $\begin{array}{l}\text { Ctenocephalides } \\
\text { Pulex } \\
\text { Heterodoxus }\end{array}$ & Absent & [102] \\
\hline Acanthocheilonema viteae & Rodents & Subcutaneous tissue & Ornithodoros & Absent & [102] \\
\hline $\begin{array}{l}\text { Acanthocheilonema } \\
\text { odendhali }\end{array}$ & Northern fur seal & - & - & Absent & [13] \\
\hline Brugia malayi & Humans & $\begin{array}{l}\text { Lymphatic system, lymph } \\
\text { nodes, testes }\end{array}$ & $\begin{array}{l}\text { Mansonia } \\
\text { Anopheles } \\
\text { Aedes }\end{array}$ & $D$ & [102] \\
\hline Brugia pahangi & Dogs, felids & $\begin{array}{l}\text { Lymphatic system, lymph } \\
\text { nodes, testes }\end{array}$ & $\begin{array}{l}\text { Anopheles } \\
\text { Aedes }\end{array}$ & $\mathrm{D}$ & [102] \\
\hline Brugia timori & Humans & $\begin{array}{l}\text { Lymphatic system, lymph } \\
\text { nodes, testes }\end{array}$ & $\begin{array}{l}\text { Anopheles } \\
\text { Aedes }\end{array}$ & $\mathrm{D}$ & [102] \\
\hline Cercopithifilaria grassii & Dogs & Subcutaneous tissue & Rhipicephalus spp. & NA & [102] \\
\hline Cercopithifilaria japonica & Ursidae (Black bear) & $\begin{array}{l}\text { Oesophageal and tracheal } \\
\text { connective tissue }\end{array}$ & - & $\mathrm{F}$ & [12] \\
\hline Cercopithifilaria crassa & Sika deer & Dermis & Ixodid ticks & Absent & [12] \\
\hline Cercopithifilaria longa & Sika deer & $\begin{array}{l}\text { Subcutaneous connective tis- } \\
\text { sues between muscles and } \\
\text { skin of limbs and trunk }\end{array}$ & Ixodid ticks & Absent & [12] \\
\hline Cercopithifiaria minuta & Japanese serow & Skin & Ixodid ticks & Absent & [12] \\
\hline Cercopithifilaria multicauda & Japanese serow & Skin & Ixodid ticks & Absent & [12] \\
\hline Cercopithifilaria roussilhoni & Brush-tailed porcupine & Skin & Ixodid ticks & Absent & [12] \\
\hline Cercopithifilaria shohoi & Japanese serow & Skin & Ixodid ticks & Absent & [12] \\
\hline $\begin{array}{l}\text { Cercopithifilaria tumidicer- } \\
\text { vicata }\end{array}$ & Japanese serow & Skin & Ixodid ticks & Absent & [12] \\
\hline Litomosa westi & Rodents & $\begin{array}{l}\text { Abdominal and pleural } \\
\text { cavities }\end{array}$ & Ornithonyssus spp. & $\mathrm{D}$ & [49] \\
\hline Litomosoides sigmodontis & Rodents & Coelomic cavity & Ornithonyssus & $\mathrm{D}$ & [102] \\
\hline Litomosoides taylori & Water nectomys & Abdominal cavity & $\begin{array}{l}\text { Suspected to be mites or } \\
\text { bat flies }\end{array}$ & $\mathrm{D}$ & [12] \\
\hline Litomosoides braziliensis & Bats & Abdominal cavity & $\begin{array}{l}\text { Suspected to be mites or } \\
\text { bat flies }\end{array}$ & $\mathrm{D}$ & {$[13,49,207]$} \\
\hline Litomosoides solarii & Bats & Abdominal cavity & $\begin{array}{l}\text { Suspected to be mites or } \\
\text { bat flies }\end{array}$ & $\mathrm{D}$ & {$[13,207]$} \\
\hline Litomosoides hamletti & Bats & Abdominal cavity & $\begin{array}{l}\text { Suspected to be mites or } \\
\text { bat flies }\end{array}$ & $\mathrm{D}$ & {$[49,207]$} \\
\hline Litomosoides galizai & Murids & Coelomic cavity & Bdellonyssus bacoti & $\mathrm{D}$ & [49] \\
\hline Litomosa chiropterorum & & & & Absent & [12] \\
\hline Litomosa yutajensis & & & & Absent & [12] \\
\hline Litomosoides chagasfilhoi & Mongolian gerbils & Abdominal cavity & Ornithonyssus bacoti & $D$ & [208] \\
\hline Loxodontofilaria caprini & Serows & $\begin{array}{l}\text { Subcutaneous tissue mainly } \\
\text { of limbs }\end{array}$ & $\begin{array}{l}\text { Simulium japonicum } \\
\text { T. japonensis (suspected } \\
\text { vector) }\end{array}$ & C & {$[12,209]$} \\
\hline Montanema martini & Typical striped grass mouse & Skin & Ixodid ticks & Absent & [12] \\
\hline Mansonella ozzardi & Humans & Coelomic cavity & $\begin{array}{l}\text { Culicoides } \\
\text { Simulium }\end{array}$ & $\mathrm{F}$ & {$[49,210]$} \\
\hline Mansonella perstans & Humans and monkeys & Coelomic cavity & Culicoides & $\mathrm{F}$ & {$[102,210]$} \\
\hline Mansonella streptocerca & Humans and monkeys & Intradermal & Culicoides grahamii & NA & {$[102,210]$} \\
\hline Mansonella perforata & Sika deer & Dermis & Culicoides spp. & $\mathrm{F}$ & {$[12,210]$} \\
\hline M. (T.) atelensis amazonae & Primates, Cebidae & Subscapular region & Culicoides spp. & $\mathrm{F}$ & {$[12,210]$} \\
\hline
\end{tabular}


Table 3 (continued)

\begin{tabular}{|c|c|c|c|c|c|}
\hline Onchocercids & Host & Location & Vector & $\begin{array}{l}\text { Wolbachia } \\
\text { supergroup }\end{array}$ & References \\
\hline Onchocerca cervicalis & Equids & Nuchal ligament & Culicoides & C & [102] \\
\hline $\begin{array}{l}\text { Onchocerca gutturosal } \\
\text { Onchocerca lienalis }\end{array}$ & Bovids & $\begin{array}{l}\text { Nuchal ligament, connec- } \\
\text { tive tissue, gastro splenic } \\
\text { ligament }\end{array}$ & $\begin{array}{l}\text { Simulium arakawae Simulium } \\
\text { daisense Simulium kyush- } \\
\text { uense } \\
\text { Culicoides }\end{array}$ & C & {$[12,209]$} \\
\hline Onchocerca lupi & Canids & - & Unknown & C & [102] \\
\hline Onchocerca ochengi & Bovids & Intradermal & Simulium & C & [102] \\
\hline Onchocerca volvulus & Humans & Subcutaneous tissue & Simulium & C & [102] \\
\hline Onchocerca armillata & $\begin{array}{l}\text { Bovids } \\
\text { occasionally } \\
\text { camel }\end{array}$ & Thoracic aorta & $\begin{array}{l}\text { Midges (Culicoides), } \\
\text { Blackflies (Simulium) }\end{array}$ & C & {$[12]$} \\
\hline Onchocerca borneensis n. sp. & Suids & Footpads of the hind limbs & & C & {$[12]$} \\
\hline $\begin{array}{l}\text { Onchocerca dewittei } \\
\text { japonica }\end{array}$ & Suids & $\begin{array}{l}\text { Nodular fibrous structures in } \\
\text { the footpads of fore- and } \\
\text { hind limbs }\end{array}$ & Simulium bidentatum & C & {$[12,207,209]$} \\
\hline Onchocerca caprini & Bovids & Skin & Simulium sp. & C & [12] \\
\hline Onchocerca suzukii & Bovids & $\begin{array}{l}\text { Subcutaneous tissue of the } \\
\text { body, mainly in the thoracic } \\
\text { area and pelvic limbs }\end{array}$ & $\begin{array}{l}\text { Simulium japonicum } \\
\text { Prosimulium sp. (Suspected } \\
\text { vector) }\end{array}$ & C & {$[12,209]$} \\
\hline Onchocerca cervipedis & Cervids & $\begin{array}{l}\text { Subcutaneous tissues of the } \\
\text { legs }\end{array}$ & $\begin{array}{l}\text { Prosimulium impostor Simu- } \\
\text { lium decorum Simulium } \\
\text { venustum }\end{array}$ & C & [211] \\
\hline Onchocerca boehmi & Equids & $\begin{array}{l}\text { Arteries and veins of the } \\
\text { limbs }\end{array}$ & Not known & C & [212] \\
\hline Onchocerca skrjabini & Cervids, bovids & $\begin{array}{l}\text { Subcutaneous tissues of } \\
\text { muzzle, hocks and to a } \\
\text { lesser extend in brisket and } \\
\text { shoulder }\end{array}$ & $\begin{array}{l}\text { Simulium arakawae, Simulium } \\
\text { bidentatum, Simulium oita- } \\
\text { num (Putative vector) }\end{array}$ & C & {$[12,209]$} \\
\hline Onchocerca eberhardi & Cervids & Carpal ligament & $\begin{array}{l}\text { Simulium arakawae, Simulium } \\
\text { bidentatum, Simulium oita- } \\
\text { num (Putative vector) }\end{array}$ & C & {$[12,209]$} \\
\hline Onchocerca gibsoni & Bovines & $\begin{array}{l}\text { Subcutaneous and intermus- } \\
\text { cular nodules }\end{array}$ & Culicoides spp. & C & [34] \\
\hline Onchocerca fasciata & Camels & $\begin{array}{l}\text { Subcutaneous tissue and } \\
\text { nuchal ligament }\end{array}$ & Unknown & - & [213] \\
\hline Onchocerca jakutensis & Red deer, humans & $\begin{array}{l}\text { Tissues of the outer thigh and } \\
\text { the caudal part of the back; } \\
\text { eye, neck and face nodules }\end{array}$ & & - & [214] \\
\hline Wuchereria bancrofti & Humans & $\begin{array}{l}\text { Lymphatic system, lymph } \\
\text { nodes, testes }\end{array}$ & $\begin{array}{l}\text { Culex } \\
\text { Anopheles } \\
\text { Aedes }\end{array}$ & $\mathrm{D}$ & [102] \\
\hline Dipetalonema gracile & Capuchin monkey & Abdominal cavity & Culicoides spp. & J & $\begin{array}{l}{[13,207,215,} \\
216]\end{array}$ \\
\hline Dipetalonema robini & New world monkey & Peritoneal cavity & Culicoides spp. & J & {$[13,207,216]$} \\
\hline Dipetalonema caudispina & New world monkey & Peritoneal cavity & Culicoides spp. & J & {$[13,207,216]$} \\
\hline Dipetalonema graciformis & New world monkey & Peritoneal cavity & Culicoides spp. & J & {$[216,217]$} \\
\hline Malayfilaria sofiani & Tree shrews & $\begin{array}{l}\text { Tissues surrounding the } \\
\text { lymph nodes of the neck }\end{array}$ & Not known & $\mathrm{D}$ & [207] \\
\hline Cruorifilaria tuberocauda & Capybara & Kidney & Not known & J & [13] \\
\hline Yatesia hydrochoerus & Capybara & Skeletal muscle & Amblyomma sp? & J & [13] \\
\hline $\begin{array}{l}\text { Breinlia (Breinlia) jitta- } \\
\text { palapongi }\end{array}$ & Tanezumi rat & Peritoneal cavity & - & Absent & [13] \\
\hline \multicolumn{6}{|l|}{ Dirofilariinae } \\
\hline Dirofilaria immitis & Canids, felids & $\begin{array}{l}\text { Right ventricle pulmonary } \\
\text { artery }\end{array}$ & Aedes & C & [102] \\
\hline
\end{tabular}


Table 3 (continued)

\begin{tabular}{|c|c|c|c|c|c|}
\hline Onchocercids & Host & Location & Vector & $\begin{array}{l}\text { Wolbachia } \\
\text { supergroup }\end{array}$ & References \\
\hline Dirofilaria repens & Canids, felids & Subcutaneous tissue & $\begin{array}{l}\text { Culex } \\
\text { Aedes }\end{array}$ & $C$ & [102] \\
\hline Loaloa & Humans & Subcutaneous tissue & Chrysops & Absent & {$[102]$} \\
\hline Foleyella candezei & Rainbow agama & Subcutaneous tissue & & Absent & [12] \\
\hline Pelecitus fulicaeatrae & Black-necked grebe & Ankle region & Lice & Absent & [13] \\
\hline \multicolumn{6}{|l|}{ Setariinae } \\
\hline Setaria equina & Horses & Coelomic cavity & Aedes & Absent & {$[102]$} \\
\hline Setaria tundra & Roedeer & Peritoneal cavity & Aedes sp., Anopheles sp. & Absent & [13] \\
\hline Setaria digitata & cattle & Peritoneal cavity & $\begin{array}{c}\text { Aedes, Culex, Anopheles, } \\
\text { Hyrcanus, Armigeres }\end{array}$ & Absent & [12] \\
\hline \multicolumn{6}{|l|}{ Splendidofilariinae } \\
\hline Cardiofilaria pavlovskyi & Eurasian golden oriole & Body and pericardial cavity & - & NA & [13] \\
\hline Madathamugadia hiepei & Turner's thick-toed gecko & - & Phlebotomus sp.? & $\mathrm{F}$ & [13] \\
\hline Aproctella sp. 1 & $\begin{array}{l}\text { Rufous-bellied Thrush } \\
\text { Green-winged saltator }\end{array}$ & - & - & Absent & {$[12]$} \\
\hline \multicolumn{6}{|l|}{ Icosiellinae } \\
\hline Icosiella neglecta & Marsh frog, Edible frog & Muscle, subcutaneous tissue & - & Absent & [13] \\
\hline \multicolumn{6}{|l|}{ Oswaldofilariinae } \\
\hline Oswaldofilaria petersi & Crocodilurus & $\begin{array}{l}\text { Mesentery, intestine and } \\
\text { thigh muscles }\end{array}$ & - & Absent & [13] \\
\hline Piratuba scaffi & Lizard jungle runner & Skin & & Absent & {$[12]$} \\
\hline \multicolumn{6}{|l|}{ Waltonellinae } \\
\hline Ochoterenella phyllomedusa & Toads & - & Culicine mosquitoes & Absent & [13] \\
\hline Ochoterenella royi & Cane toad & - & - & Absent & {$[12]$} \\
\hline Ochoterenella sp. 1 & Giant leaf frog & - & - & Absent & {$[12]$} \\
\hline
\end{tabular}

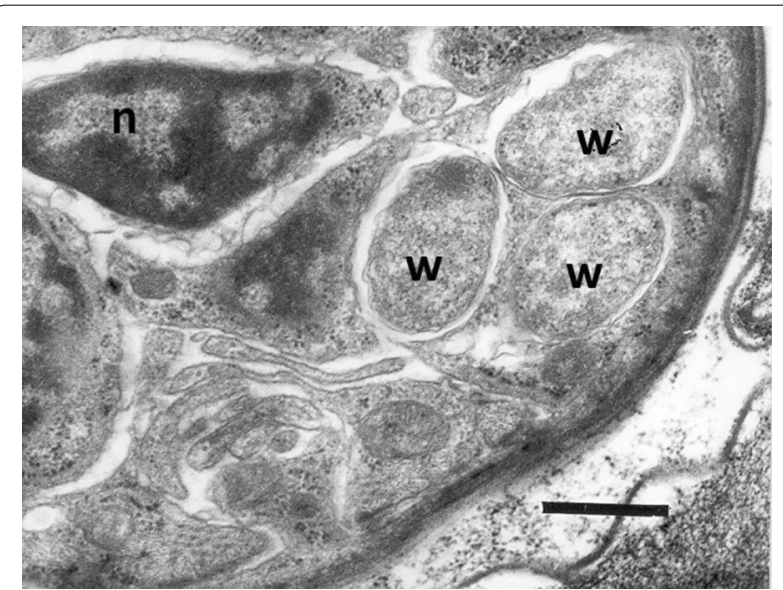

Fig. 1 Wolbachia in an embryo of the nematode Dirofilaria immitis (transmission electron microscopy observation). W: Wolbachia bacteria; n: nucleus; scale bar: $0.6 \mu \mathrm{m}$ (Photograph of Luciano Sacchi and Claudio Bandi, Modified from Bergey's Manual of Systematic Bacteriology, volume 2: The Proteobacteria) [221] open question that needs to be addressed by the scientific community along with the screening of new drug targets for filarial control.

\section{Wolbachia as a modulator of host inflammation and immunity}

Filariasis has an extremely complex immunopathology with adult parasites surviving in immune competent patients for many years [49]. Many filarial nematodes harbour Wolbachia at all stages of their life cycle [49] except a few species such as L. loa, Acanthocheilonema viteae, O. flexuosa and Setaria equina [106, 109]. One of the main concerns in the treatment of filarial worms is related to the host inflammatory response provoked by the death of adult or larval worms within the parasitized tissues [77]. Under the above circumstances, the use of doxycycline targeting Wolbachia causes a soft killing of onchocercid nematodes with a slow death of adult parasites (over 12-24 months), preceded by a block of embryogenesis and larval development with clearing of microfilariae from blood or skin, thus preventing the pathology [110-112]. However, Wolbachia also plays a major role in the pathogenesis of both acute and chronic 
filariasis, which may cause severe systemic adverse reactions to chemotherapy as well as ocular inflammation by activating pro-inflammatory and immunomodulatory mechanisms in the host in cases of $O$. volvulus infection [113] (Fig. 2). Hence, Wolbachia has multiple roles in filariasis (i.e. activation of proinflammatory pathogenesis, immunomodulation of the host and survival of the parasite) starting from the entry of the parasite to the establishment of the infection [102].

Wolbachia stimulates a proinflammatory immune response to onchocercid nematodes by interacting with the host monocytes, macrophages, dendritic cells and neutrophils [77]. Indeed, Wolbachia may elicit a host immune response by activating the innate and adaptive responses in human and murine models of filariasis infection [102]. Generally, in bacterial infections, the host innate immune system recognises pathogenassociated molecular patterns (PAMP) associated with bacteria which are presented by pattern recognition receptors (PRP) including the Toll-like receptors (TLR) located on the surface of antigen-presenting cells [77] (Fig. 2). Though lipopolysaccharides (LPS) act as a major PAMP in most bacterial infections, the absence of genes required for LPS biosynthesis in the Wolbachia genomes suggests that the Wolbachia surface protein (WSP) is a predominant PAMP involved in the immunopathology of filarial diseases $[106,114,115]$. Recently, further evidence on the immune-modulating property of WSP showed that the Asaia endosymbiotic bacterium engineered for the expression of this protein induces classical macrophage activation, associated with the killing of Leishmania parasites [116].

In addition to WSP, other PAMPs of Wolbachia include HSP 60 and groEL, and all these molecules mainly elicit TLR 2 or TLR 6 recognition and signalling [77]. In particular, WSP produces inflammation and regulatory marker expression (i.e. T lymphocyte antigen 4) while HSP 60 acts on monocytes and produces cytokines and TNF $\alpha$, which induce an adaptive immune response against onchocercid nematodes [102, 113, 117]. Hence, in O. volvulus pathology, TLR 2 activates macrophages and local stromal cells contributing to the neutrophil-mediated corneal inflammation and permanent destruction of the cornea $[118,119]$. In chronically ill patients, repeated invasion of larvae and their death produce inflammatory cell influx, eventually causing permanent tissue damage by neutrophil degranulation and the production of cytotoxic products such as nitric oxide (NO), myeloperoxidase and oxygen radicals [119]. It is believed that, in bancroftian patients, Wolbachia with its TLR2 signalling triggers vascular endothelial growth factor A and angiopoietin-1 production, which produces the dilatation of

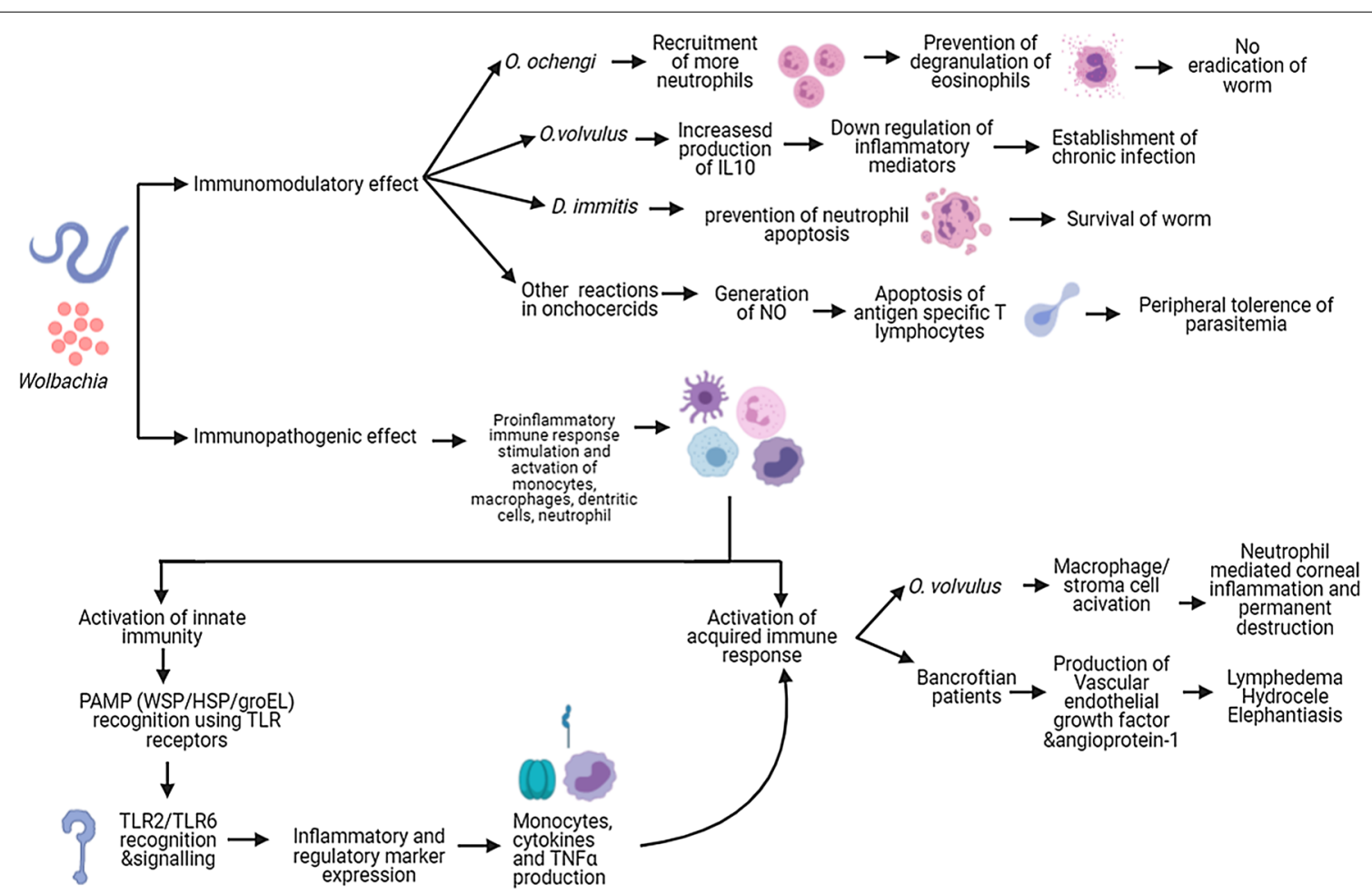

Fig. 2 Role of Wolbachia in onchocecid nematode infections. Wolbachia induced changes in the host immune system such as immunomodulation for the survival of nematodes and various steps in the development of the immunopathology in filarial diseases are summarized 
scrotal lymph vessels [120] (Fig. 2). This is supported by the results obtained after the administration of doxycycline [121]. Absence of such immunological response by the extracts of the worm A. viteae, which have no Wolbachia endosymbiont, supports the above findings [113, 117].

In addition to the contribution in immunopathology, Wolbachia plays a defensive mutualistic role in filarial biology (e.g. O. ochengi) by triggering the recruitment of more neutrophils, which will help to prevent the degranulation of eosinophils needed for the eradication of filarial worms [122]. A similar reaction is also observed in human D. immitis infection wherein WSP prevent the neutrophil apoptosis [123]. Moreover, further in vitro studies on blood cells from patients with $O$. volvulus suggested that chronic Wolbachia stimulation may cause the downregulation of pro-inflammatory mediators by increasing the production of interleukin 10 (IL-10) and thus help in establishing chronic infection [124]. In addition, it is suggested that together with filarial antigens, Wolbachia may induce generation of NO, which aids in the peripheral tolerance through apoptosis of antigenspecific $\mathrm{T}$ lymphocytes [125]. This manipulation of the host immune system helps to increase the longevity of onchocercid nematodes [126, 127] (Fig. 2). Moreover, a stronger immune reaction in response to the release of L3 larvae than to the dead worm indicates the predominant role of these bacteria at the development of the early stage of the worm [77]. Wolbachia with its TLR 2-dependent signalling helps the filarial L3 larva establishment by surpassing chemokine (c-c motif) ligand 17 (CCL 17)-mediated immune response of the host [128].

\section{Exploiting Wolbachia for treatment}

Current filariasis treatment control and Mass Drug Administration (MDA) programmes are focussed on the use of microfilaricides such as albendazole combined with either ivermectin or diethylcarbamazine [129]. Though this treatment regime helped to reduce the number of human cases of filariases, the long duration of treatment (e.g. 17 years for onchocerciasis and 5 years for lymphatic filariasis), the development of resistance to ivermectin in endemic areas as well as adverse reactions to ivermectin treatment in certain epidemiological conditions (e.g. onchocerciasis-loasis co-endemic areas) hampered the global elimination of the diseases [110, 130]. Hence, chronic debilitating pathological alterations and the economic burdens in endemic countries due to long-term treatment and control programmes highlighted the need for an alternative effective short-term potential drug target for filariasis.

Based on the unique obligatory symbiotic relationship Wolbachia has established with these onchocercid nematodes (e.g. embryogenesis and moulting) and the role of these bacteria in the immunopathology of filarial diseases, a major mission of the anti-Wolbachia (A.WOL) consortium was to exploit the Wolbachiafilarial biology for controlling human infection [131]. Studies suggested that anti-Wolbachia therapy has both macrofilaricidal (i.e. death of adult parasites and developmental retardation) and microfilaricidal embryotoxic activity. Indeed, antibacterial agents such as doxycycline were found to be effective in clearing microfilarial stages from the blood and skin of patients, therefore preventing filarial pathology and reducing the transmission [131]. Moreover, the slow death of adult parasites over a period of 12-24 months in patients treated with doxycycline is safe to use in geographical regions were onchocerciasis and loiasis occurred in sympatry [110-112]. However, the mechanism of action of doxycycline in the treatment of filariases was not well understood until transcriptomic and proteomic analysis unveiled that the responses of Wolbachia to doxycycline cause impairment of bacterial metabolism [132]. Meta-analytical modelling suggests that a 4-week doxycycline course suffices to eliminate Wolbachia with low chances of developing drug resistance when compared to other antibiotics like penicillin or fluoroquinolones [133, 134]. However, the limited use of this drug in pregnancy, lactating mothers and children motivated the scientific community to search for other anti-Wolbachia drugs $[127,131]$. As a result, more than 2 million compounds have been tested in insect cell lines and A.WOL was formed with the objective to identify new anti-Wolbachia drugs with a short course of therapy, which could be safe in contraindicated groups $[135,136]$. Mass screening of all registered antibacterials revealed four drugs as superior to doxycycline with minocycline as the most effective drug of choice [137]. Recent experimental trials claim that the use of Tylosin A, a macrofilaricide, is superior to tetracycline antibiotics (e.g. doxycycline and minocycline) and will help to reduce the duration of treatment from 3-4 to 1-2 weeks [131].

\section{Targeting Wolbachia for vector control}

Vector control methods mainly focus on the physical removal of their breeding sites in the environment or on- and off-host application of insecticides targeting immature or adult stages [138]. A combination of factors such as human population growth, globalization, rapid rise in population-dense towns, expansion of the geographical range of vectors and development of insecticide resistance affected the control of vectors and associated pathogens $[139,140]$. Hence, the search for an alternative vector control approach may target either reducing the vector population or modifying the vector to make it refractory to pathogen transmission [138]. 
For example, the abundance of Wolbachia among vectors and its high rate of maternal transmission conjoined with CI have spurred the interest of researchers in new target strategies for vector control. It was discovered that Wolbachia can protect its natural host Drosophila melanogaster from pathogenic viruses, such as Drosophila C virus $[138,141]$. Since then, many Wolbachia strains have been found to block the transmission of a range of medically important viruses and parasites [138, 142]. Thus, it was proposed that the use of large numbers of Wolbachia-infected males to sterilize local uninfected females through CI (incompatible insect technique, IIT) coupled with a pathogen-blocking Wolbachia strain could be effectively gradually replace the local permissive natural vectors with refractory insects [143]. Therefore, a non-profit research consortium, namely the "World Mosquito Program" (WMP), formerly known as the "Eliminate Dengue Program", was instituted to eliminate mosquito-borne viral diseases like dengue, Zika and chikungunya [141, 144]. In this context, it has been shown that the intensity of Wolbachia infection is directly correlated with the strength of pathogen blocking and the tissue damage caused by the cellular load of highly replicative strains of Wolbachia (e.g. wMelPop) produces pathogen blocking in Ae. aegypti [145]. Other possible mechanisms are host immune priming by the preactivation of the immune response and gene regulation by the induction of Vagol protein, which is involved in the innate immune pathways of Culex quinquefasciatus and Ae. aegypti. This mechanism could favour vectors to reduce West Nile and dengue virus replication $[146,147]$. Though vectors like Ae. aegypti are not naturally infected with the virus inhibiting Wolbachia, these non-native strains of Wolbachia were introduced into the vectors of medical and veterinary importance by transfection [148] (Fig. 3). Other methods such as transient somatic infection, infections in cell lines, ex vivo organ culture, outcrossing and introgression can also be used for the successful introduction of Wolbachia in non-native vectors [147] (Table 4). Current research on control mainly focuses on limiting the susceptibility to infection rather than using this symbiont to reduce the life span of vectors [149]. Indeed, the fitness cost of wMelPop strain prompted the researchers to adopt another strain of Wolbachia, wMel which does not reduce the fitness of mosquito hosts [149, 150]. Approximately 300,000 $w$ Mel-infected Ae. aegypti mosquitoes were released in north Queensland over a period of 10 weeks [149]. The

\section{Aedes aegypti MOSQUITOES}

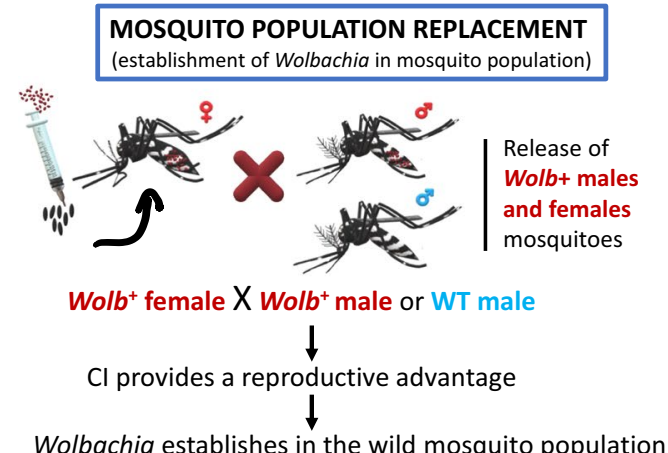

Wolbachia establishes in the wild mosquito population

Immune priming, competition for metabolites, alteration of the expression of host miRNAs

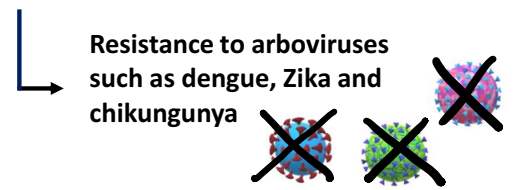

MOSQUITO POPULATION REDUCTION OR SUPPRESSION

(Wolbachia for an Incompatible insect technique, male sterilization)

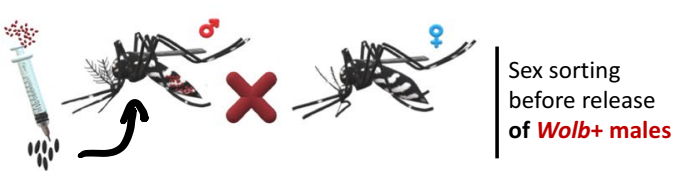

Wolb+ male X WT female or Wolb+ female (incompatible strain) $\downarrow$

Limited or no effect on male mating competitiveness and survival

$\mathrm{Cl}$ incompatible matings and embryonic death

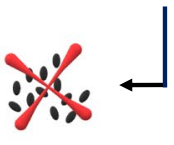

Mosquito population reduction or suppression Reduction of the incidence of vector-borne diseases

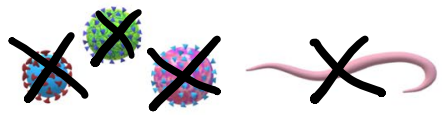

Fig. 3 Exploiting Wolbachia for vector control. Left panel: mosquito population replacement approach, in which Wolbachia-infected female and male mosquitoes are released; through $\mathrm{Cl}$, this strategy allows the spread of Wolbachia in the natural population. The presence of Wolbachia provides a fitness advantages (determined by $\mathrm{Cl}$ ) and can reduce the arbovirus transmission. Right panel: mosquito population reduction or suppression strategy. This approach involves the release of Wolbachia-infected males into an area; when these mosquitoes mate with wild Wolbachia-negative females (or female mosquitoes harbouring an incompatible strain of Wolbachia), a strong reduction in the rate of egg hatching is observed (Cl incompatible matings). Thus, repeated releases of Wolbachia-infected males result in reduction or suppression of mosquito populations. Cl cytoplasmic incompatibility, WT wild-type mosquitoes, Wolb + Wolbachia-infected mosquitoes 


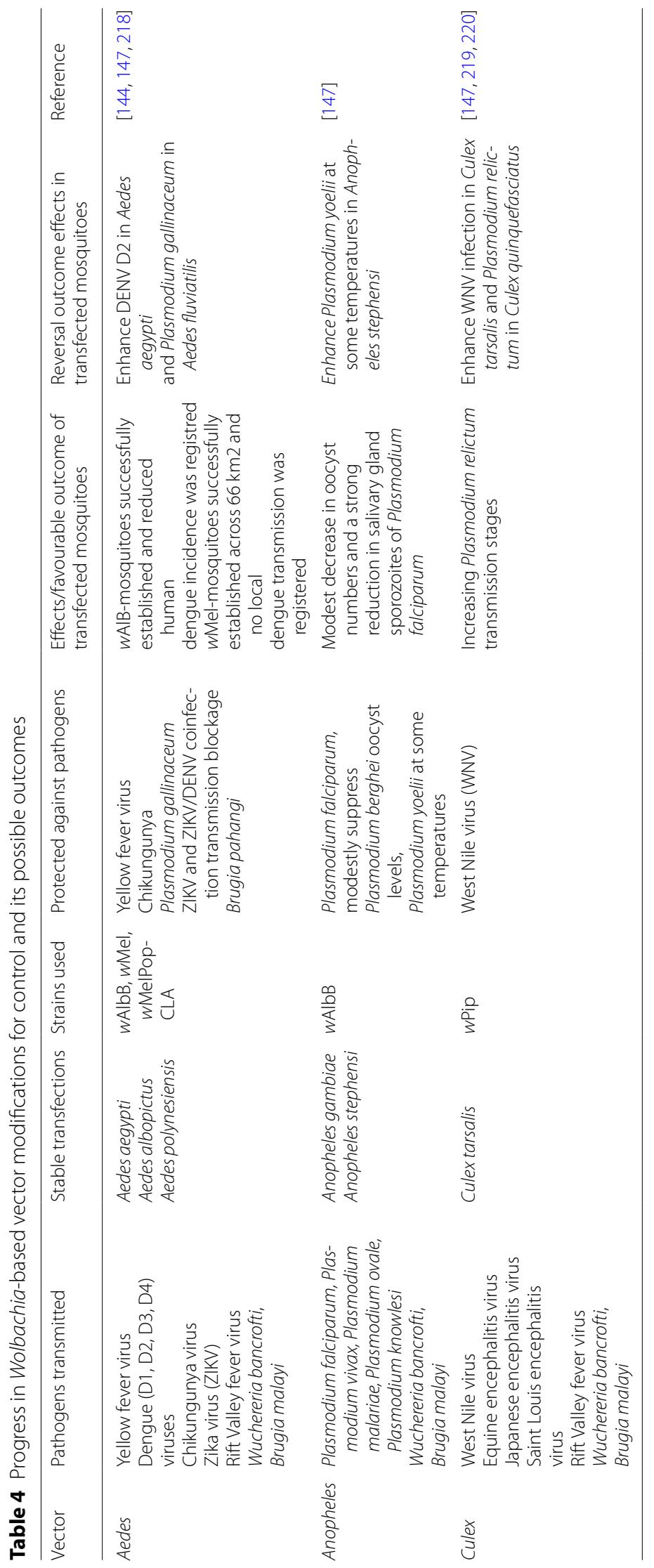


success of this strategy in north Queensland (i.e. a high infection frequency up to $80 \%-90 \%$ ) was replicated in 12 countries, including Brazil, Indonesia, Vietnam, and four countries of the south-western Pacific region [141]. These studies have shown that the wMel strain of Wolbachia can quickly spread to near fixation in the wild mosquito population and become stable for a long time after the initial release [138]. Apart from these, in West Africa, stable Wolbachia infections were recently detected in natural Anopheles populations and these infections appear to be negatively correlated to Plasmodium prevalence, which opens up the possibility of utilising these endosymbionts for the control of malaria transmission [143]. The introduction of Wolbachia infections in Culicoides sonorensis cell lines and the upregulation of immune genes in the same vectors suggested the utility of using Wolbachia as a bio-control agent in the transmission of $C$. sonorensis vectored pathogens of veterinary importance (e.g. African horse sickness virus, Schmallenberg virus, bluetongue virus, epizootic hemorrhagic disease virus) [151]. Like any other modern technologies, Wolbachia-based vector control also has some potential vulnerabilities such as (i) loss of attenuation of Wolbachia infection in the mosquito, (ii) emergence of virus strains that are resistant to Wolbachia-mediated blocking, (iii) increasing virulence and disease pathogenesis in humans, (iv) enhancement of the arbovirus infection in transfected mosquitoes and (v) development of mutations in viruses over time that render them less susceptible or resistant to Wolbachia [141]. Apart from these the current method of control requires continual release of large numbers of males to suppress the mosquito population and the migration of mosquitoes from the untreated surroundings will hinder the long-term effectiveness of this method. Since only modified males are released into the environment, adoption of an effective sex sorting system is required [138]. Nonetheless, none of these modifying technologies has yet been approved by the WHO's Vector Control Advisory Group [138]. In addition, it is highly advisable to avoid adverse effects such as the enhancement of pathogen development in coinfections (Table 4) by analysing the molecular mechanisms of Wolbachiapathogen interactions before doing the field trials.

\section{Conclusions and future perspectives}

Though Wolbachia is a relatively well-studied endosymbiont [4], there are still lacunae in the knowledge about its exact distribution, evolution, type of symbiosis and $\mathrm{Wol}$ bachia-mediated antiparasitic mechanisms. It has been hypothesised that onchocercid nematodes may depend on Wolbachia for their heme metabolism [17]. For example, no new biosynthesis pathways for heme metabolism are observed in L. loa, which lacks Wolbachia [17], therefore suggesting alternative pathways or the presence of other symbionts for the essential nutritional requirement of these worms. While Wolbachia is already well studied, many other endosymbionts have received less attention, such as some Spiroplasma, Cardinium, Arsenophonus and Flavobacetrium species [152] and have not yet been investigated in detail. So, the metagenomics approach could help to assess the associated endosymbionts in Wolbachia free onchocercid nematodes. In addition, the use fluorescence in situ hybridization is advisable to assess the natural infections by Wolbachia [153]. Since Wolbachia dominant proteins expressed in each life stage of onchocercid nematodes show a gradual increase from L1 to adult $[16,96]$, proteomic approaches (e.g. mass spectrometry, chromatography) could be useful to assess their variation in expression in each stage in the vector and the definitive host for their survival and multiplication. This may eventually lead to exploring the type of symbiosis at each stage of the parasite life cycle, also providing insights into the Wolbachia-mediated antiparasite mechanisms and potential new drug targets for onchocercid nematodes of medical and veterinary significance. Despite doxycycline being adopted to treat filarial diseases, potential difficulties (e.g. drug adherence, toxicity, resistance, financial cost, contraindications in pregnant women and children) limit its use in the public health MDA programmes [127]. Promising in vitro drug trials with new antibiotics (e.g. berberine, rapamycin, globomycin, succinyl acetone) [106, 154-156] and the effectiveness of non-antimicrobial compounds such as anti-oxidants and anti-histamines open a new window onto filarial treatment [127]. Further clinical trials using these drugs may provide an innovative strategy for antiWolbachia treatment, eventually reducing the duration of treatment.

Overall, the prevalence of Wolbachia differs significantly among different climatic regions and geographic locations [157]. For example, the intensity of Wolbachia infections in natural Ae. albopictus populations was low in regions with only imported dengue cases suggesting a positive correlation with the presence of Wolbachia in vectors and dengue infection [157]. Based on the above, it would be necessary to have a cluster-randomized design, involving either long- or short-term vectorrelease trials in limited locations or in more sites, respectively, to optimize the impact of this control strategy in each geographical or climatic setting [158]. Nonetheless, Wolbachia-based vector control strategies to control arboviral infections targeting Aedes aegypti are being compromised in many endemic countries because of the co-localisation of the secondary vector Aedes albopictus [159]. Hence, it is important to rely also on fluorescence in situ hybridisation when reporting natural Wolbachia 
infections and not only on PCR. Furthermore, use of multiple strains of Wolbachia for vector transfection and integration of CI-carrying phage elements into strains that are devoid of them (e.g. wAu) [159] could provide more fitness benefits for the transfected vector. Under the above circumstances, transfected triple-strain infection of Wolbachia (e.g. wMel and $w$ Pip and $w \mathrm{Au}$ ) into a Malaysian Ae. albopictus line produced self-compatibility, moderate fitness cost and complete resistance to Zika and dengue infections [160]. Apart from these, more field trials using $w \mathrm{AlbB}$ strains will also help to overcome the inability of $w$ MelPop strains to establish in wild mosquito populations or the $w \mathrm{Mel}$ strains to survive at high temperatures in the field [161]. This could be considered a successful strategy to reduce the incidence of dengue in an endemic area of Malaysia after the release of $w$ AlbBinfected Ae aegypti [161]. Similarly, use of other endosymbionts along with Wolbachia will help to accelerate the control of $D$. immitis through the use of genetically engineered Asaia bacteria for the expression of WSP from their Wolbachia endosymbionts [80]. However, the untoward effects of Wolbachia such as irreversible biological effects and reversal outcome on disease transmission [162] should be properly addressed before clinical trials. Successful introduction of Wolbachia infections in Anopheles gambiae, Anopheles stephensi and C. sonorensis cell lines may give a breakthrough in the control of malaria, African horse sickness, Schmallenberg, bluetongue and epizootic hemorrhagic disease. The genome sequencing of the Wolbachia strain, wIrr, of Haematobia irritans irritans suggests its unique features, including the horizontal acquisition of additional transcriptionally active CI loci, which may be exploited for the biocontrol and potential insecticide resistance of horn flies [163]. Despite all the challenges, studies on Wolbachia and their use in the control and/or treatment of vectors, onchocercid nematodes and viral diseases of medical and veterinary importance offer new approaches which undoubtedly open new avenues for the control of a variety of vector-borne diseases.

\footnotetext{
Abbreviations

Cl: Cytoplasmic incompatibility; PAMP: Pathogen-associated molecular pattern marker; TLR: Toll-like receptors; LPS: Lipopolysaccharides; Interleukin: IL; HSP: Heat shock protein; WSP: Wolbachia surface protein; LAMP: Loop-mediated isothermal amplification; NO: Nitric oxide; MDA: Mass drug administration; WMP: World Mosquito Program.

\section{Acknowledgements}

The authors are thankful to all the researchers whose studies have been reviewed in this manuscript. The authors are thankful to Luciano Sacchi for providing the pictures of Wolbachia in the embryo of Dirofilaria immitis. The authors acknowledge the use of BioRender software for the preparation of Fig. 2.
}

\section{Authors' contributions}

RRSM and DO conceived the review. RRSM wrote the first draft. RRSM and DO reviewed and undertook the data abstraction from the selected articles and revised the manuscript. MSL and SE participated in the preparation of the review. RRSM and SE created the figures and assessed the data. MSL and SE assisted in editing the review. All authors read and approved the final manuscript.

\section{Funding}

This work receives no funding.

\section{Availability of data and materials}

All datasets supporting the conclusions of this article are included within the article.

\section{Declarations}

Ethics approval and consent to participate

Not applicable.

\section{Consent for publication \\ Not applicable.}

\section{Competing interests}

All authors declare that they have no competing interests.

\section{Author details}

${ }^{1}$ Department of Veterinary Medicine, University of Bari, Valenzano, Italy. 'Department of Biosciences and Pediatric CRC 'Romeo Ed Enrica Invernizzi', University of Milan, Milan, Italy. ${ }^{3}$ Faculty of Veterinary Sciences, Bu-Ali Sina University, Hamedan, Iran.

Received: 8 January 2021 Accepted: 23 April 2021

Published online: 07 May 2021

References

1. Sullivan W. Wolbachia, bottled water, and the dark side of symbiosis. Mol Biol Cell. 2017;28:2343-6.

2. Hosokawa T, Koga R, Kikuchi Y, Meng XY, Fukatsu T. Wolbachia as a bacteriocyte-associated nutritional mutualist. Proc Natl Acad Sci USA. 2010;107:769-74.

3. Nikoh N, Hosokawa T, Moriyama M, Oshima K, Hattori M, Fukatsu T. Evolutionary origin of insect-Wolbachia nutritional mutualism. Proc Natl Acad Sci. 2014;111:10257-62.

4. Werren JH, Baldo L, Clark ME. Wolbachia: master manipulators of invertebrate biology. Nat Rev Microbiol. 2008;6:741-51.

5. Thrash JC, Boyd A, Huggett MJ, Grote J, Carini P, Yoder RJ, et al. Phylogenomic evidence for a common ancestor of mitochondria and the SAR11 clade. Sci Rep. 2011;1:13.

6. Kozek WJ, Rao RU. The discovery of Wolbachia in arthropods and nematodes-A historical perspective. In: Hoerauf A, Rao RU, editors. Wolbachia: a bug's life in another bug. Basel: Karger; 2007. p. 1-14.

7. Hertig M. The rickettsia, Wolbachia pipientis (gen et sp n) and associated inclusions of the mosquito Culex pipiens. Parasitology. 1936;28:453-86.

8. Kozek, WJ. 1967. The ultrastructure of the microfilaria of Dirofilaria immitis. M.S. thesis, Tulane University. p. 142.

9. Harada R, Maeda T, Nakashima A, Sadakata Y, Ando M, Yonamine K, et al. Electronmicroscopical studies on the mechanism of oogenesis and fertilization in Dirofilaria immitis. 1970.

10. Lee CC. Dirofilaria immitis: ultrastructural aspects of oocyte development and zygote formation. Exp Parasitol. 1975;37:449-68.

11. Sironi M, Bandi C, Sacchi L, Di Sacco B, Damiani G, Genchi C. Molecular evidence for a close relative of the arthropod endosymbiont Wolbachia in a filarial worm. Mol Biochem Parasitol. 1995;74:223-7.

12. Ferri E, Bain O, Barbuto M, Martin C, Lo N, Uni S, et al. New insights into the evolution of Wolbachia infections in filarial nematodes inferred from a large range of screened species. PLoS One. 2011;6:e20843. 
13. Lefoulon E, Bain O, Makepeace BL, d'Haese C, Uni S, Martin C, et al. Breakdown of coevolution between symbiotic bacteria Wolbachia and their filarial hosts. PeerJ. 2016:4:e1840.

14. Haegeman A, Vanholme B, Jacob J, Vandekerckhove TT, Claeys M, Borgonie G, Gheysen G. An endosymbiotic bacterium in a plant-parasitic nematode: member of a new Wolbachia supergroup. Int J Parasitol. 2009;39:1045-54.

15. Brown AM, Wasala SK, Howe DK, Peetz AB, Zasada IA, Denver DR. Genomic evidence for plant-parasitic nematodes as the earliest Wo/bachia hosts. Sci Rep. 2016;6:1-4

16. Bandi C, Trees AJ, Brattig NW. Wolbachia in filarial nematodes: evolutionary aspects and implications for the pathogenesis and treatment of filarial diseases. Vet Parasitol. 2001:98:215-38.

17. Foster J, Ganatra M, Kamal I, Ware J, Makarova K, Ivanova N, et al. The Wolbachia genome of Brugia malayi: endosymbiont evolution within a human pathogenic nematode. PLos biol. 2005;3:e121.

18. Stouthamer R, Breeuwer JA, Hurst GD. Wolbachia pipientis: microbial manipulator of arthropod reproduction. Annu Rev Microbiol. 1999:53:71-102

19. Werren JH, O'Neill SL. The evolution of heritable symbionts. In: O'Neill S, Hoffmann AA, Werren JH, editors. Influential passengers: inherited microorganisms and arthropod reproduction. Oxford: Oxford University Press; 1997. p. 1-41.

20. Weinert LA, Werren JH, Aebi A, Stone GN, Jiggins FM. Evolution and diversity of Rickettsia bacteria. Bmc Biol. 2009;7:1-5.

21. Sassera D, Lo N, Epis S, D'Auria G, Montagna M, Comandatore F, et al Phylogenomic evidence for the presence of a flagellum and $\mathrm{cbb}(3)$ oxidase in the free-living mitochondrial ancestor. Mol Biol Evol. 2011:28:3285-96

22. Correa CC, Ballard JW. Wolbachia associations with insects: winning or losing against a master manipulator. Front Ecol Evol. 2016;3:153.

23. Lefoulon E, Clark T, Guerrero R, Cañizales I, Cardenas-Callirgos JM, Junker K, Vallarino-Lhermitte N, Makepeace BL, Darby AC, Foster JM, Martin C. Diminutive, degraded but dissimilar: Wolbachia genomes from filarial nematodes do not conform to a single paradigm. Microbial genomics. 2020;6(12):e000487.

24. Wu M, Sun LV, Vamathevan J, Riegler M, Deboy R, Brownlie JC, et al. Phylogenomics of the reproductive parasite Wolbachia pipientis w Mel: a streamlined genome overrun by mobile genetic elements. PLoS Biol. 2004;2:e69.

25. Fenn K, Conlon C, Jones M, Quail MA, Holroyd NE, Parkhill J, et al. Phylogenetic relationships of the Wolbachia of nematodes and arthropods. PLoS Pathog. 2006;2:e94.

26. Lefoulon E, Clark T, Borveto F, Perriat-Sanguinet M, Moulia C, Slatko BE, Gavotte L. Pseudoscorpion Wolbachia symbionts: diversity and evidence for a new supergroup S. BMC Microbiol. 2020;20:1-5.

27. Rowley SM, Raven RJ, McGraw EA. Wolbachia pipientis in Australian spiders. Curr Microbiol. 2004;49:208-14.

28. Baldo L, Werren JH. Revisiting Wolbachia supergroup typing based on WSP: spurious lineages and discordance with MLST. Curr Microbiol. 2007:55:81-7.

29. Wang GH, Jia LY, Xiao JH, Huang DW. Discovery of a new Wolbachia supergroup in cave spider species and the lateral transfer of phage WO among distant hosts. Infect Genet Evol. 2016;41:1-7.

30. Gerth M. Classification of Wolbachia (Alphaproteobacteria, Rickettsiales): no evidence for a distinct supergroup in cave spiders. BioRxiv. 2016:046169.

31. Glowska E, Dragun-Damian A, Dabert M, Gerth M. New Wolbachia supergroups detected in quill mites (Acari: Syringophilidae). Infect Genet Evol. 2015;30:140-6.

32. Ros VL, Fleming VM, Feil EJ, Breeuwer JA. How diverse is the genus Wolbachia? Multiple-gene sequencing reveals a putatively new Wolbachia supergroup recovered from spider mites (Acari: Tetranychidae). Appl Environ Microbiol. 2009:75:1036-43.

33. Rasgon JL, Scott TW. Phylogenetic characterization of Wolbachia symbionts infecting Cimex lectularius L. and Oeciacus vicarius Horvath (Hemiptera: Cimicidae). J Med Entomol. 2004;41:1175-8.

34. Casiraghi M, Favia G, Cancrini G, Bartoloni A, Bandi C. Molecular identification of Wolbachia pipientis from the filarial nematode Mansonella ozzardi. Parasitol Res. 2001;87:417-20.
35. Casiraghi M, Bordenstein SR, Baldo L, Lo N, Beninati T, Wernegreen JJ, et al. Phylogeny of Wolbachia pipientis based on gltA, groEL and ftsZ gene sequences: clustering of arthropod and nematode symbionts in the F supergroup, and evidence for further diversity in the Wolbachia tree. Microbiology. 2005;151:4015-22.

36. Keiser PB, Coulibaly Y, Kubofcik J, Diallo AA, Klion AD, Traoré SF, et al. Molecular identification of Wolbachia from the filarial nematode Mansonella perstans. Mol Biochem Parasitol. 2008;160:123-8.

37. Lefoulon E, Gavotte L, Junker K, Barbuto M, Uni S, Landmann F, Laaksonen S, Saari S, Nikander S, de Souza LS, Casiraghi M. A new type F Wolbachia from Splendidofilariinae (Onchocercidae) supports the recent emergence of this supergroup. Int J Parasitol. 2012;42:1025-36.

38. Werren JH, Windsor D, Guo LR. Distribution of Wolbachia among neotropical arthropods. Proc R Soc Lond [Biol]. 1995;262:197-204.

39. Bandi C, Anderson TJC, Genchi C, Blaxter ML. Phylogeny of Wolbachia pipientis in filarial nematodes. Proc R Soc Lond B. 1998;265:2407-13.

40. Baldo L, Hotopp JC, Jolley KA, Bordenstein SR, Biber SA, Choudhury $\mathrm{RR}$, et al. Multilocus sequence typing system for the endosymbiont Wolbachia pipientis. Appl Environ Microbiol. 2006;72:7098-110.

41. Zug R, Koehncke A, Hammerstein P. Epidemiology in evolutionary time: the case of Wolbachia horizontal transmission between arthropod host species. J Evol Biol. 2012;25:2149-60.

42. Covacin C, Barker SC. Supergroup F Wolbachia bacteria parasitise lice (Insecta: Phthiraptera). Parasitol Res. 2007;100:479-85.

43. Haine ER, Pickup NJ, Cook JM. Horizontal transmission of Wolbachia in a Drosophila community. Ecol Entomol. 2005;30:464-72.

44. Cordaux R, Michel-Salzat A, Bouchon D. Wolbachia infection in crustaceans: novel hosts and potential routes for horizontal transmission. J Evol Biol. 2001;14:237-43.

45. Vavre F, Fouillet P, Fleury F. Phylogenetic evidence for horizontal transmission of Wolbachia in host-parasitoid associations. Mol Biol Evol. 1999;16:1711-23.

46. Kittayapong P, Jamnongluk W, Thipaksorn A, Milne JR, Sindhusake C. Wolbachia infection complexity among insects in the tropical rice-field community. Mol Ecol. 2003;12:1049-60.

47. McNulty SN, Fischer K, Curtis KC, Weil GJ, Brattig NW, Fischer PU. Localization of Wolbachia-like gene transcripts and peptides in adult Onchocerca flexuosa worms indicates tissue specific expression. Parasit vectors. 2013;6:2.

48. Lefoulon E, Giannelli A, Makepeace BL, Mutafchiev Y, Townson S, Uni $\mathrm{S}$, et al. Whence river blindness? The domestication of mammals and host-parasite co-evolution in the nematode genus Onchocerca. Int J Parasitol. 2017:47:457-70.

49. Casiraghi M, Bain O, Guerrero R, Martin C, Pocacqua V, Gardner SL, et al. Mapping the presence of Wolbachia pipientis on the phylogeny of filarial nematodes: evidence for symbiont loss during evolution. Int J Parasitol. 2004:34:191-203.

50. O'Neill SL, Giordano R, Colbert AM, Karr TL, Robertson HM. 16S rRNA phylogenetic analysis of the bacterial endosymbionts associated with cytoplasmic incompatibility in insects. Proc Natl Acad Sci USA. 1992;89:2699-702.

51. Zhou W, Rousset F, O'Neill S. Phylogeny and PCR-based classification of Wolbachia strains using wsp gene sequences. Proc R Soc B Biol Sci. 1998;265:509-15.

52. Braig HR, Zhou W, Dobson SL, O'Neill SL. Cloning and characterization of a gene encoding the major surface protein of the bacterial endosymbiont Wolbachia pipientis. J Bacteriol. 1998;180:2373-8.

53. Masui S, Sasaki T, Ishikawa H. groE-homologous operon of Wolbachia, an intracellular symbiont of arthropods: a new approach for their phylogeny. Zoolog Sci. 1997;14:701-6.

54. Simões PM, Mialdea G, Reiss D, Sagot MF, Charlat S. Wolbachia detection: an assessment of standard PCR protocols. Mol Ecol Resour. 2011;11:567-72.

55. Kondo N, ljichi N, Shimada M, Fukatsu T. Prevailing triple infection with Wolbachia in Callosobruchus chinensis (Coleoptera: Bruchidae). Mol Ecol. 2002;11:167-80.

56. Narita S, Nomura M, Kageyama D. Naturally occurring single and double infection with Wolbachia strains in the butterfly Eurema hecabe: transmission efficiencies and population density dynamics of each Wolbachia strain. FEMS microbiol ecol. 2007;61:235-45 
57. JamnonglukW, Kittayapong P, Baimai V, O'Neill SL. Wolbachia infections of tephritid fruit flies: molecular evidence for five distinct strains in a single host species. Current Microbiol. 2002;45:255-60.

58. Perrot-Minnot MJ, Guo LR, Werren JH. Single and double infections with Wolbachia in the parasitic wasp Nasonia vitripennis effects on compatibility. Genet. 1996;143:961-72.

59. da Silva GD, Hooker DJ, Dong Y, Baran N, Kyrylos P, Iturbe-Ormaetxe I, et al. Detecting wMel Wolbachia in field-collected Aedes aegypti mosquitoes using loop-mediated isothermal amplification (LAMP). Parasit Vectors. 2019;12:404.

60. Salzberg SL, Dunning Hotopp JC, Delcher AL, Pop M, Smith DR, Eisen MB, Nelson WC. Serendipitous discovery of Wolbachia genomes in multiple Drosophila species. Genome Biol. 2005;6:R23.

61. Richardson MF, Weinert LA, Welch JJ, Linheiro RS, Magwire MM, Jiggins FM, et al. Population genomics of the Wolbachia endosymbiont in Drosophila melanogaster. PLoS Genet. 2012;8:e1003129.

62. Saha S, Hunter WB, Reese J, Morgan JK, Marutani-Hert M, Huang H, et al. Survey of endosymbionts in the Diaphorina citri metagenome and assembly of a Wolbachia wDi draft genome. PLoS One. 2012;7:e50067.

63. Pascar J, Chandler CH. A bioinformatics approach to identifying Wolbachia infections in arthropods. PeerJ. 2018;6:e5486.

64. Darby AC, Armstrong SD, Bah GS, Kaur G, Hughes MA, Kay SM, et al. Analysis of gene expression from the Wolbachia genome of a filarial nematode supports both metabolic and defensive roles within the symbiosis. Genome Res. 2012;22:2467-77.

65. Cotton JA, Bennuru S, Grote A, Harsha B, Tracey A, et al. The genome of Onchocerca volvulus, agent of river blindness. Nat Microbiol. 2016;2:1-2.

66. Lebov JF, Mattick J, Libro S, Sparklin BC, Chung M, Bromley RE, et al. Complete genome sequence of $W \mathrm{Bp}$, the Wolbachia endosymbiont of Brugia pahangi FR3. Microbiol Resour Announc. 2020;9:1.

67. Chung M, Small ST, Serre D, Zimmerman PA, Dunning Hotopp JC. Draft genome sequence of the Wolbachia endosymbiont of Wuchereria bancrofti wWb. Pathog Dis. 2017:75:115.

68. Ellegaard KM, Klasson L, Näslund K, Bourtzis K, Andersson SG. Comparative genomics of Wolbachia and the bacterial species concept. PLoS Genet. 2013;9:e1003381.

69. Comandatore F, Cordaux R, Bandi C, Blaxter M, Darby A, et al. Supergroup C Wolbachia, mutualist symbionts of filarial nematodes, have a distinct genome structure. Open Biol. 2015;5:150099.

70. Jeyaprakash A, Hoy MA. Long PCR improves Wolbachia DNA amplification: wsp sequences found in $76 \%$ of sixty-three arthropod species. Insect Mol Biol. 2000:9:393-405.

71. Sinkins SP, Braig HR, O'Neill SL. Wolbachia superinfections and the expression of cytoplasmic incompatibility. Proc R Soc Lond [Biol]. 1995;261:325-30.

72. Arthofer W, Riegler M, Schneider D, Krammer M, Miller WJ, Stauffer C. Hidden Wolbachia diversity in field populations of the European cherry fruit fly, Rhagoletis cerasi (Diptera, Tephritidae). Mol Ecol. 2009;18:3816-30.

73. Atyame CM, Delsuc F, Pasteur N, Weill M, Duron O. Diversification of Wolbachia endosymbiont in the Culex pipiens mosquito. Mol Biol Evol. 2011;28:2761-72.

74. Martinez J, Tolosana I, Ok S, Smith S, Snoeck K, Day JP, et al. Symbiont strain is the main determinant of variation in Wolbachia-mediated protection against viruses across Drosophila species. Mol Ecol. 2017:26:4072-84

75. Bandi C, Dunn AM, Hurst GD, Rigaud T. Inherited microorganisms, sex-specific virulence and reproductive parasitism. Trends Parasitol. 2001;17:88-94.

76. Kremer N, Voronin D, Charif D, Mavingui P, Mollereau B, Vavre F. Wolbachia interferes with ferritin expression and iron metabolism in insects. PLoS Pathog. 2009;5:e1000630

77. Genchi C, H Kramer L, Sassera D, Bandi C. Wolbachia and its implications for the immunopathology of filariasis. Endocr Metab Immune Disord Drug Targets. 2012;12:53-6.

78. Teixeira L, Ferreira A, Ashburner M. The bacterial symbiont Wolbachia induces resistance to RNA viral infections in Drosophila melanogaster. PLoS Biol. 2008:6:2753-63.

79. Kambris Z, Cook PE, Phuc HK, Sinkins SP. Immune activation by lifeshortening Wolbachia and reduced filarial competence in mosquitoes. Science. 2009:326:134-6.
80. Epis S, Varotto-Boccazzi I, Crotti E, Damiani C, Giovati L, Mandrioli M, et al. Chimeric symbionts expressing a Wolbachia protein stimulate mosquito immunity and inhibit filarial parasite development. Commun Biol. 2020;3:105.

81. Kambris Z, Blagborough AM, Pinto SB, Blagrove MS, Godfray HC, Sinden RE, et al. Wolbachia stimulates immune gene expression and inhibits Plasmodium development in Anopheles gambiae. PLoS pathog. 2010;6:e1001143.

82. Dobson SL, Bourtzis K, Braig HR, Jones BF, Zhou W, Rousset F, et al. Wolbachia infections are distributed throughout insect somatic and germ line tissues. Insect Biochem Mol Biol. 1999;29:153-60.

83. Kittayapong P, Baisley KJ, Baimai V, O'Neill SL. Distribution and diversity of Wolbachia infections in Southeast Asian mosquitoes (Diptera: Culicidae). J Med Entomol. 2000;37:340-5.

84. Cordaux R, Bouchon D, Grève P. The impact of endosymbionts on the evolution of host sex-determination mechanisms. Trends Genet. 2011;27:332-41.

85. Kageyama D, Ohno M, Sasaki T, Yoshido A, Konagaya T, Jouraku A, et al. Feminizing Wolbachia endosymbiont disrupts maternal sex chromosome inheritance in a butterfly species. Evol Lett. 2017;1:232-44.

86. Negri I, Pellecchia M, Dubey R. Sex steroids in insects and the role of the endosymbiont Wolbachia: a new perspective. Sex Hs. 2012:353-74.

87. Marhold J, Rothe N, Pauli A, Mund C, Kuehle K, Brueckner B, et al. Conservation of DNA methylation in dipteran insects. Insect Mol Biol. 2004;13:117-23.

88. Rances E, Yixin HY, Woolfit M, McGraw EA, O'Neill SL. The relative importance of innate immune priming in Wolbachia-mediated dengue interference. PLoS Pathog. 2012;8:1.

89. Ye HY, Woolfit M, Huttley GA, Rancès E, Caragata EP, Popovici J, et al. Infection with a virulent strain of Wolbachia disrupts genome widepatterns of cytosine methylation in the mosquito Aedes aegypti. PLoS One. 2013;8:e66482.

90. Evans O, Caragata EP, McMeniman CJ, Woolfit M, Green DC, Williams $\mathrm{CR}$, et al. Increased locomotor activity and metabolism of Aedes aegypti infected with a life-shortening strain of Wolbachia pipientis. J Exp Biol. 2009:212:1436-41.

91. Hedges LM, Brownlie JC, O'Neill SL, Johnson KN. Wolbachia and virus protection in insects. Science. 2008;322:702.

92. Bian G, Joshi D, Dong Y, Lu P, Zhou G, Pan X, et al. Wolbachia invades Anopheles stephensi populations and induces refractoriness to Plasmodium infection. Science. 2013;340:748-51.

93. Blagrove MS, Arias-Goeta C, Di Genua C, Failloux AB, Sinkins SP. A Wolbachia wMel transinfection in Aedes albopictus is not detrimental to host fitness and inhibits Chikungunya virus. PLoS Negl Trop Dis. 2013;7:e2152

94. Asgari S. Epigenetic modifications underlying symbiont-host interactions. Adv Genet. 2014;86:253-76.

95. Martin C, Gavotte L. The bacteria Wolbachia in filariae, a biological Russian dolls' system: new trends in antifilarial treatments. Parasite. 2010;17:79-89.

96. Fenn K, Blaxter M. Quantification of Wolbachia bacteria in Brugia malayi through the nematode lifecycle. Mol Biochem Parasitol. 2004;2:361-4.

97. Bain O, Casiraghi M, Martin C, Uni S. The nematode Filarioidea: critical analysis linking molecular and traditional approaches. Parasite. 2008;15:342-8.

98. Uni S. Filarial parasites of the black bear of Japan. Ann Parasit Hum Comp. 1983;58:71-84

99. Uni S, Bain O, Takaoka H, Miyshita M, Suziki Y. Onchocerca dewittei japonica n. subsp., a common parasite from wild in Kyushu Island Japan. Parasite. 2001:8:215-22.

100. Hoerauf A, Mand S, Volkmann L, Büttner M, Marfo-Debrekyei Y, Taylor M, et al. Doxycycline in the treatment of human onchocerciasis: kinetics of Wolbachia endobacteria reduction and of inhibition of embryogenesis in female Onchocerca worms. Microbes Infect. 2003:5:261-73.

101. Uni S, Bain O, Agatsuma T, Katsumi A, Baba M, Yanai T, et al. New filarial nematode from Japanese serows (Naemorhedus crispus: Bovidae) close to parasites from elephants. Parasite. 2006;13:193-200.

102. Bouchery T, Lefoulon E, Karadjian G, Nieguitsila A, Martin C. The symbiotic role of Wolbachia in Onchocercidae and its impact on filariasis. Clin Microbiol Infect. 2013;19:131-40. 
103. Landmann F, Foster JM, Slatko B, Sullivan W. Asymmetric Wolbachia segregation during early Brugia malayi embryogenesis determines its distribution in adult host tissues. PLoS Negl Trop Dis. 2010;4:e758.

104. Strübing U, Lucius R, Hoerauf A, Pfarr KM. Mitochondrial genes for heme-dependent respiratory chain complexes are up-regulated after depletion of Wolbachia from filarial nematodes. Int J Parasitol. 2010;40:1193-202.

105. Casiraghi M, McCall JW, Simoncini L, Kramer LH, Sacchi L, Genchi C, et al. Tetracycline treatment and sex-ratio distortion: a role for Wolbachia in the moulting of filarial nematodes? Int J Parasitol. 2002;32:1457-68.

106. Wu B, Novelli J, Foster J, Vaisvila R, Conway L, Ingram J, et al. The heme biosynthetic pathway of the obligate Wolbachia endosymbiont of Brugia malayi as a potential anti-filarial drug target. PLoS Negl Trop Dis. 2009;3:e475.

107. Desjardins CA, Cerqueira GC, Goldberg JM, Hotopp JC, Haas BJ, Zucker J, et al. Genomics of Loa loa, a Wolbachia free filarial parasite of humans. Nature Genet. 2013;45:495-500.

108. McGarry HF, Pfarr K, Egerton G, Hoerauf A, Akue JP, Enyong P, et al. Evidence against Wolbachia symbiosis in Loa loa. Filaria J. 2003;2:1-7.

109. Chirgwin SR, Porthouse KH, Nowling JM, Klei TR. The filarial endosymbiont Wolbachia sp. is absent from Setaria equina. J Parasitol. 2002;88:1248-50.

110. Taylor MJ, Hoerauf A, Bockarie M. Lymphatic filariasis and onchocerciasis. Lancet. 2010;376:1175-85.

111. Slatko BE, Taylor MJ, Foster JM. The Wolbachia endosymbiont as an antifilarial nematode target. Symbiosis. 2010;51:55-65.

112. Walker M, Specht S, Churcher TS, Hoerauf A, Taylor MJ, Basáñez MG. Therapeutic efficacy and macrofilaricidal activity of doxycycline for the treatment of river blindness. Clin Infect Dis. 2015;60:1199-207.

113. Brattig NW, Rathjens U, Ernst M, Geisinger F, Renz A, Tischendorf FW. Lipopolysaccharide-like molecules derived from Wolbachia endobacteria of the filarial Onchocerca volvulus are candidate mediators in the sequence of inflammatory and anti-inflammatory responses of human monocytes. Microbes Infect. 2000;2:1147-57.

114. Bazzocchi C, Ceciliani F, McCall JW, Ricci I, Genchi C, Bandi C. Antigenic role of the endosymbionts of filarial nematodes: IgG response against the Wolbachia surface protein in cats infected with Dirofilaria immitis. Proc Biol Sci. 2000;267:2511-6.

115. Brattig NW, Bazzocchi C, Kirschning CJ, Reiling N, Büttner DW, Ceciliani $\mathrm{F}$, et al. The major surface protein of Wolbachia endosymbionts in filarial nematodes elicits immune responses through TLR2 and TLR4. J Immunol. 2004;173:437-45.

116. Varotto-Boccazzi I, Epis S, Arnoldi I, Corbett Y, Gabrieli P, Paroni M, et al. Boosting immunity to treat parasitic infections: Asaia bacteria expressing a protein from Wolbachia determine M1 macrophage activation and killing of Leishmania protozoans. Pharmacol Res. 2020;161:105288.

117. Taylor MJ, Cross HF, Bilo K. Inflammatory responses induced by the filarial nematode Brugia malay are mediated by lipopolysaccharide like activity from endosymbiotic Wolbachia bacteria. J Exp Med. 2000;191:1429-36.

118. Gentil K, Pearlman E. Gamma interferon and interleukin-1 receptor 1 regulate neutrophil recruitment to the corneal stroma in a murine model of Onchocerca volvulus keratitis. Infect Immun. 2009;77:1606-12.

119. Tamarozzi F, Halliday A, Gentil K, Hoerauf A, Pearlman E, Taylor MJ. Onchocerciasis: the role of Wolbachia bacterial endosymbionts in parasite biology, disease pathogenesis, and treatment. Clin Microbiol Rev. 2011;24:459-68.

120. Babu S, Anuradha R, Kumar NP, George PJ, Kumaraswami V, Nutman TB. Toll-like receptor- and filarial antigen-mediated, mitogen-activated protein kinase- and NF-kappaB-dependent regulation of angiogenic growth factors in filarial lymphatic pathology. Infect Immun. 2012;80:2509-18.

121. Mand S, Pfarr K, Sahoo PK, Satapathy AK, Specht S, Klarmann U, et al. Macrofilaricidal activity and amelioration of lymphatic pathology in bancroftian filariasis after 3 weeks of doxycycline followed by singledose diethylcarbamazine. Am J Trop Med Hyg. 2009;81:702-11.

122. Turner JD, Langley RS, Johnston KL, Gentil K, Ford L, Wu B, et al. Wolbachia lipoprotein stimulates innate and adaptive immunity through Toll-like receptors 2 and 6 to induce disease manifestations of filariasis. J Biolog Chem. 2009;284:22364-78.
123. Bazzocchi C, Comazzi S, Santoni R, Bandi C, Genchi C, Mortarino M. Wolbachia surface protein (WSP) inhibits apoptosis in human neutrophils. Parasite Immunol. 2007;29:73-9.

124. Brattig NW. Pathogenesis and host responses in human onchocerciasis: impact of Onchocerca filariae and Wolbachia endobacteria. Microbes Infect. 2004;6:113-28.

125. O'Connor RA, Jenson JS, Osborne J, Devaney E. An enduring association? Microfilariae and immunosupression in lymphatic filariasis. Trends Parasitol. 2003;19:565-70.

126. Hansen RD, Trees AJ, Bah GS, Hetzel U, Martin C, Bain O, et al. A worm's best friend: recruitment of neutrophils by Wolbachia confounds eosinophil degranulation against the filarial nematode Onchocerca ochengi. Proc Biol Sci. 2011;278:2293-302.

127. Sulaiman WA, Kamtchum-Tatuene J, Mohamed MH, Ramachandran V, Ching SM, Lim SM, et al. Anti-Wolbachia therapy for onchocerciasis \& lymphatic filariasis: Current perspectives. Indian J Med Res. 2019;149:706.

128. Specht S, Frank JK, Alferink J, Dubben B, Layland LE, Denece G, et al. CCL17 controls mast cells for the defense against filarial larval entry. J Immunol. 2011;186:4845-52.

129. World Health Organization. WHO Lymphatic Filariasis. Fact Sheet. World Health Organization; 2020. https://www.who.int/news-room/ fact-sheets/detail/lymphatic-filariasis

130. Osei-Atweneboana MY, Awadzi K, Attah SK, Boakye DA, Gyapong JO, Prichard RK. Phenotypic evidence of emerging ivermectin resistance in Onchocerca volvulus. PLoS Negl Trop Dis. 2011;5:e998.

131. Taylor MJ, von Geldern TW, Ford L, Hübner MP, Marsh K, Johnston KL, et al. Preclinical development of an oral anti-Wolbachia macrolide drug for the treatment of lymphatic filariasis and onchocerciasis. Sci Transl Med. 2019;11:eaau2086.

132. Darby AC, Gill AC, Armstrong SD, Hartley CS, Xia D, Wastling JM, et al. Integrated transcriptomic and proteomic analysis of the global response of Wolbachia to doxycycline-induced stress. ISME J. 2014;8:925-37.

133. Suputtamongkol Y, Niwattayakul K, Suttinont C, Losuwanaluk K, Limpaiboon R, Chierakul W, et al. An open, randomized, controlled trial of penicillin, doxycycline, and cefotaxime for patients with severe leptospirosis. Clin Infect Dis. 2004;39:1417-24.

134. Brouillard JE, Terriff CM, Tofan A, Garrison MW. Antibiotic selection and resistance issues with fluoroquinolones and doxycycline against bioterrorism agents. Pharmacotherapy. 2006;26:3-14.

135. Johnston KL, Ford L, Umareddy I, Townson S, Specht S, Pfarr K, et al. Repurposing of approved drugs from the human pharmacopoeia to target Wolbachia endosymbionts of onchocerciasis and lymphatic filariasis. Int J Parasitol Drugs Drug Resist. 2014;4:278-86.

136. Clare RH, Cook DA, Johnston KL, Ford L, Ward SA, Taylor MJ. Development and validation of a high-throughput anti-Wolbachia whole-cell screen: a route to macrofilaricidal drugs against onchocerciasis and lymphatic filariasis. J Biomol Screen. 2015;20:64-9.

137. Taylor MJ, Hoerauf A, Townson S, Slatko BE, Ward SA. Anti-Wolbachia drug discovery and development: Safe macrofilaricides for onchocerciasis and lymphatic filariasis. Parasitology. 2014;141:119-27.

138. Flores HA, O'Neill SL. Controlling vector-borne diseases by releasing modified mosquitoes. Nat Rev Microbiol. 2018;16:508-18.

139. Mayer SV, Tesh RB, Vasilakis N. The emergence of arthropod-borne viral diseases: A global prospective on dengue, chikungunya and zika fevers. Acta Trop. 2017;166:155-63.

140. Bonizzoni M, Gasperi G, Chen X, James AA. The invasive mosquito species Aedes albopictus: current knowledge and future perspectives. Trends Parasitol. 2013;29:460-8.

141. Van den Hurk AF. From Incriminating Stegomyia fasciata to Releasing Wolbachia pipientis: Australian Research on the Dengue Virus Vector, Aedes aegypti, and Development of Novel Strategies for Its Surveillance and Control. Trop Med Infect Dis. 2018:3:71.

142. Lindsey AR, Bhattacharya T, Newton IL, Hardy RW. Conflict in the intracellular lives of endosymbionts and viruses: A mechanistic look at Wolbachia-mediated pathogen-blocking. Viruses. 2018;10:141.

143. Shaw WR, Catteruccia F. Vector biology meets disease control: using basic research to fight vector-borne diseases. Nat Microbiol. 2019;4:20-34. 
144. O'Neill SL. The use of Wolbachia by the World Mosquito Program to interrupt transmission of Aedes aegypti transmitted viruses. In: Dengue and Zika: Control and Antiviral Treatment Strategies .Singapore:Springer; 2018. p. 355-360.

145. Terradas G, McGraw EA. Wolbachia-mediated virus blocking in the mosquito vector Aedes aegypti. Curr Opin Insect Sci. 2017;22:37-44.

146. Asad S, Parry R, Asgari S. Upregulation of Aedes aegypti Vago 1 by Wolbachia and its effect on dengue virus replication. Insect Biochem Mol Biol. 2018;92:45-52.

147. Niang EH, Bassene H, Fenollar F, Mediannikov O. Biological control of mosquito-borne diseases: the potential of Wolbachia-Based Interventions in an IVM Framework. J Trop Med. 2018;2018:1470459.

148. McMeniman CJ, Lane RV, Cass BN, Fong AW, Sidhu M, Wang YF, et al. Stable introduction of a life-shortening Wolbachia infection into the mosquito Aedes aegypti. Science. 2009;323:141-4.

149. Hoffmann AA, Montgomery BL, Popovici J, Iturbe-Ormaetxe I, Johnson PH, Muzzi F, et al. Successful establishment of Wolbachia in Aedes populations to suppress dengue transmission. Nature. 2011;476(7361):454-7.

150. Yeap HL, Mee P, Walker T, Weeks AR, O'Neill SL, Johnson P, et al. Dynamics of the "popcorn" Wolbachia infection in outbred Aedes aegypti informs prospects for mosquito vector control. Genet. 2011;187:583-95.

151. Ghosh A, Jasperson D, Cohnstaedt LW, Brelsfoard CL. Transfection of Culicoides sonorensis biting midge cell lines with Wolbachia pipientis. Parasit Vectors. 2019;12:483.

152. Duron O, Bouchon D, Boutin S, Bellamy L, Zhou L, Engelstadter J, et al. The diversity of reproductive parasites among arthropods: Wolbachia do not walk alone. BMC Biol. 2008;6:27.

153. Hughes GL, Koga R, Xue P, Fukatsu T, Rasgon JL. Wolbachia infections are virulent and inhibit the human malaria parasite Plasmodium falciparum in Anopheles gambiae. PLoS Pathog. 2011;7:e1002043.

154. Li Z, Garner AL, Gloeckner C, Janda KD, Carlow CK. Targeting the Wolbachia cell division protein FtsZ as a new approach for antifilarial therapy. PLoS Negl Trop Dis. 2010;5:1411.

155. Voronin D, Cook DA, Steven A, Taylor MJ. Autophagy regulates Wolbachia populations across diverse symbiotic associations. Proc Natl Acad Sci. 2012;109:E1638-46.

156. Johnston KL, Wu B, Guimarães A, Ford L, Slatko BE, Taylor MJ. Lipoprotein biosynthesis as a target for anti-Wolbachia treatment of filarial nematodes. Parasit Vectors. 2010;3:1.

157. Hu Y, Xi Z, Liu X, Wang J, Guo Y, Ren D, et al. Identification and molecular characterization of Wolbachia strains in natural populations of Aedes albopictus in China. Parasit Vectors. 2020;13:28.

158. Dorigatti I, McCormack C, Nedjati-Gilani G, Ferguson NM. Using Wolbachia for dengue control: insights from modelling. Trends Parasitol. 2018;34:102-13.

159. Mancini MV, Herd CS, Ant TH, Murdochy SM, Sinkins SP. Wolbachia strain wAu efficiently blocks arbovirus transmission in Aedes albopictus. PLOS Negl Trop Dis. 2020;14:e0007926.

160. Ant TH, Sinkins SP. A Wolbachia triple-strain infection generates selfincompatibility in Aedes albopictus and transmission instability in Aedes aegypti. Parasit Vectors. 2018;11:295.

161. Ekwudu O, Devine GJ, Aaskov JG, Frentiu FD. Wolbachia strain wAlbB blocks replication of flaviviruses and alphaviruses in mosquito cell culture. Parasit Vectors. 2020;13:54.

162. Nazareth T, Craveiro I, Moutinho A, Seixas G, Gonçalves C, Gonçalves L, et al. What happens when we modify mosquitoes for disease prevention? A systematic review. Emerg Microbes Infect. 2020;9:348-65.

163. Madhav M, Parry R, Morgan JA, James P, Asgari S. Wolbachia endosymbiont of the horn fly (Haematobia irritans irritans): a Supergroup A strain with multiple horizontally acquired cytoplasmic incompatibility genes. Appl Environ Microbiol. 2020;86:1.

164. O'Neill SL, Karr TL. Bidirectional incompatibility between conspecific populations of Drosophila simulans. Nature. 1990;348(6297):178-80.

165. Werren $\mathrm{JH}$, Windsor DM. Wolbachia infection frequencies in insects: evidence of a global equilibrium? Proc R Soc Lond [Biol]. 2000;267:1277-85.

166. Sakamoto JM, Rasgon JL. Geographic distribution of Wolbachia infections in Cimex lectularius (Heteroptera: Cimicidae). J Med Entomol. 2006;43:696-700.
167. Carvajal TM, Hashimoto K, Harnandika RK, Amalin DM, Watanabe K. Detection of Wolbachia in field-collected Aedes aegypti mosquitoes in metropolitan Manila. Philippines Parasit Vectors. 2019;12:361.

168. Egyed Z, Sréter T, Széll Z, Nyirő G, Márialigeti K, Varga I. Molecular phylogenetic analysis of Onchocerca lupi and its Wolbachia endosymbiont. Vet Parasitol. 2002;108:153-61.

169. Anderson ML, Rustin RC, Eremeeva ME. Pilot survey of mosquitoes (Diptera: Culicidae) from southeastern Georgia, USA for Wolbachia and Rickettsia felis (Rickettsiales: Rickettsiaceae). J Vector Borne Dis. 2019;56:92-7.

170. Sawasdichai S, Chaumeau V, Dah T, Kulabkeeree T, Kajeechiwa L, Phanaphadungtham M, et al. Detection of diverse Wolbachia $16 \mathrm{~S}$ rRNA sequences at low titers from malaria vectors in Kayin state Myanmar. Wellcome Open Res. 2019;4:1.

171. Nugapola NN, De Silva WP, Karunaratne SP. Distribution and phylogeny of Wolbachia strains in wild mosquito populations in Sri Lanka. Parasit Vectors. 2017:10:230.

172. Armoo S, Doyle SR, Osei-Atweneboana MY, Grant WN. Significant heterogeneity in Wolbachia copy number within and between populations of Onchocerca volvulus. Parasit Vectors. 2017;10:188.

173. Jasper ME, Yang Q, Ross PA, Endersby-Harshman N, Bell N, Hoffmann AA. A LAMP assay for the rapid and robust assessment of Wolbachia infection in Aedes aegypti under field and laboratory conditions. PLoS One. 2019;14:e0225321.

174. Zha X, Zhang W, Zhou C, Zhang L, Xiang Z, Xia Q. Detection and characterization of Wolbachia infection in silkworm. Genet Mol Biol. 2014;37:573-80.

175. Satjawongvanit H, Phumee A, Tiawsirisup S, Sungpradit S, Brownell N, Siriyasatien P, et al. Molecular analysis of canine filaria and its Wolbachia endosymbionts in domestic dogs collected from two animal university hospitals in Bangkok Metropolitan Region Thailand. Pathog. 2019;8:114

176. McGarry HF, Egerton GL, Taylor MJ. Population dynamics of Wolbachia bacterial endosymbionts in Brugia malayi. Mol Biochem Parasitol. 2004;135:57-67.

177. Shaikevich E, Bogacheva A, Ganushkina L. Dirofilaria and Wolbachia in mosquitoes (Diptera: Culicidae) in central European Russia and on the Black Sea coast. Parasite. 2019;26:1.

178. Ruang-Areerate T, Kittyapong P, Baimai V, O'Neill SL. Molecular phylogeny of Wolbachia endosymbionts in Southeast Asian mosquitoes (Diptera: Culicidae) based on wsp gene sequences. J Med Entomol. 2003;40:1-5.

179. Dean JL, Dobson SL. Characterization of Wolbachia infections and interspecific crosses of Aedes (Stegomyia) polynesiensis and Ae.(Stegomyia) riversi (Diptera: Culicidae). J Med Entomol. 2004;41:894-900.

180. Koenraadt CJ, Takken W. Ecology of parasite-vector interactions: expect the unexpected. In: Takken W, Koenraadt CJ, editors. Ecology and control of vector-borne diseases. Wageningen: Wageningen Academic Publishers; 2013. p. 247-51.

181. Ricci I, Cancrini G, Gabrielli S, D'amelio S, Favia G. Searching for Wolbachia (Rickettsiales: Rickettsiaceae) in mosquitoes (Diptera: Culicidae): large polymerase chain reaction survey and new identifications. J Med Entomol. 2002;39:562-7.

182. Moreira LA, Iturbe-Ormaetxe I, Jeffery JA, Lu G, Pyke AT, Hedges LM et al. A Wolbachia symbiont in Aedes aegypti limits infection with dengue, Chikungunya, and Plasmodium. Cell. 2009;139:1268-78.

183. Osei-Poku J, Han C, Mbogo CM, Jiggins FM. Identification of Wolbachia strains in mosquito disease vectors. PLoS One. 2012;7:1.

184. Ayala D, Akone-Ella O, Rahola N, Kengne P, Ngangue MF, Mezeme F, et al. Natural Wolbachia infections are common in the major malaria vectors in Central Africa. Evol Appl. 2019;12:1583-94.

185. Baldini F, Segata N, Pompon J, Marcenac P, Shaw WR, Dabiré RK, et al. Evidence of natural Wolbachia infections in field populations of Anopheles gambiae. Nat Commun. 2014;5:3985.

186. Gomes FM, Hixson BL, Tyner MD, Ramirez JL, Canepa GE, e-Silva TL, et al. Effect of naturally occurring Wolbachia in Anopheles gambiae s.l. mosquitoes from Mali on Plasmodium falciparum malaria transmission. Proc Natl Acad Sci USA. 2017;114:12566-71.

187. Bordbar A, Soleimani S, Fardid F, Zolfaghari MR, Parvizi P. Three strains of Wolbachia pipientis and high rates of infection in Iranian sandfly species. Bull Entomol Res. 2014;104:195-202. 
188. Parvizi P, Bordbar A, Najafzadeh N. Detection of Wolbachia pipientis, including a new strain containing the wsp gene, in two sister species of Paraphlebotomus sandflies, potential vectors of zoonotic cutaneous leishmaniasis. Mem Inst Oswaldo Cruz. 2013;108(4):414-20.

189. Vivero RJ, Cadavid-Restrepo G, Herrera CX, Soto SI. Molecular detection and identification of Wolbachia in three species of the genus Lutzomyia on the Colombian Caribbean coast. Parasit Vectors. 2017;10:110.

190. Mirkery-Pachecho O, Marina C, Ibañez B, Sanchez D, Castillo V. Infeccion natural de Lutzomyia cruciata (Diptera: Psychodidae, Phlebotominae) con Wolbachia en cafetales de Chiapas. México Act Zoológica Mex. 2012:8:401-13.

191. Azpurua J, De La Cruz D, Valderama A, Windsor D. Lutzomyia sand fly diversity and rates of infection by Wolbachia and an exotic Leishmania species on Barro Colorado Island Panama. PLoS Negl Trop Dis. 2010;4:e627.

192. Pagès N, Muñoz-Muñoz F, Verdún M, Pujol N, Talavera S. First detection of Wolbachia-infected Culicoides (Diptera: Ceratopogonidae) in Europe: Wolbachia and Cardinium infection across Culicoides communities revealed in Spain. Parasit Vectors. 2017;10:582.

193. Mee PT, Weeks AR, Walker PJ, Hoffmann AA, Duchemin JB. Detection of low-level Cardinium and Wolbachia infections in Culicoides. Appl Environ Microbiol. 2015;81:6177-88.

194. Crainey JL, Wilson MD, Post RJ. Phylogenetically distinct Wolbachia gene and pseudogene sequences obtained from the African onchocerciasis vector Simulium squamosum. Int J Parasitol. 2010;40:569-78.

195. Crainey JL, Hurst J, Lamberton PH, Cheke RA, Griffin CE, Wilson MD, et al. The genomic architecture of novel Simulium damnosum Wolbachia prophage sequence elements and implications for onchocerciasis epidemiology. Front Microbiol. 2017;8:852.

196. Mingchay P, Sai-Ngam A, Phumee A, Bhakdeenuan P, Lorlertthum K, Thavara $U$, et al. Wolbachia supergroups $A$ and $B$ in natural populations of medically important filth flies (Diptera: Muscidae, Calliphoridae, and Sarcophagidae) in Thailand Southeast Asian. J Trop Med Public Health. 2014;45:309.

197. Dittmar K, Whiting MF. New Wolbachia endosymbionts from nearctic and neotropical fleas (Siphonaptera). J Parasitol. 2004;90:953-7.

198. Gorham CH, Fang QQ, Durden LA. Wolbachia endosymbionts in fleas (Siphonaptera). J Parasitol. 2003;89:283-9.

199. Luchetti A, Mantovani B, Fioravanti ML, Trentini M. Wolbachia infection in the newly described Ecuadorian sand flea Tunga trimamillata. Exp Parasitol. 2004;108:18-23.

200. Pampiglione S, Fioravanti ML, Gustinelli A, Onore G, Mantovani B, Luchetti A, et al. Sand flea (Tunga spp.) infections in humans and domestic animals: state of the art. Med Vet Entomol. 2009;23:172-86.

201. Jones RT, Borchert J, Eisen R, MacMillan K, Boegler K, Gage KL. Fleaassociated bacterial communities across an environmental transect in a plague-endemic region of Uganda. PLoS One. 2015;10:e0141057.

202. Bezerra-Santos MA, Nogueira BC, Yamatogi RS, Ramos RA, Galhardo JA, Campos AK. Ticks, fleas and endosymbionts in the ectoparasite fauna of the black-eared opossum Dipelphis aurita in Brazil. Exp Appl Acarol. 2020;80:329-38.

203. Rasgon JL, Scott TW. An initial survey for Wolbachia (Rickettsiales: Rickettsiaceae) infections in selected California mosquitoes (Diptera: Culicidae). J Med Entomol. 2004;41:255-7.

204. Hirunkanokpuna S, Ahantarigb A, Baimaib V, Trinachartvanitb W. A new record of Wolbachia in the elephant ticks from Thailand. Science Asia. 2018:44:44-7.

205. Hartelt K, Oehme R, Frank H, Brockmann SO, Hassler D, Kimmig P. Pathogens and symbionts in ticks: prevalence of Anaplasma phagocytophilum (Ehrlichia sp.), Wolbachia sp., Rickettsia sp., and Babesia sp. in Southern Germany. Int J Med Microbiol Suppl. 2004;293:86-92.
206. Konecka E, Olszanowski Z, Koczura R. Wolbachia of phylogenetic supergroup E identified in oribatid mite Gustavia microcephala (Acari: Oribatida). Mol Phylogenet Evol. 2019;135:230-5.

207. Uni S, Udin AS, Agatsuma T, Junker K, Saijuntha W, Bunchom N, et al. Description, molecular characteristics and Wolbachia endosymbionts of Onchocerca borneensis Uni, Mat Udin \& Takaoka n. sp. (Nematoda: Filarioidea) from the Bornean bearded pig Sus barbatus Müller (Cetartiodactyla: Suidae) of Sarawak. Malaysia Parasit Vectors. 2020;13:50.

208. Chagas-Moutinho VA, Silva R, de Souza W, Motta MC. Identification and ultrastructural characterization of the Wolbachia symbiont in Litomosoides chagasfilhoi. Parasit Vectors. 2015;8:74.

209. Takaoka H, Fukuda M, Otsuka Y, Aoki C, Uni S, Bain O. Blackfly vectors of zoonotic onchocerciasis in Japan. Med Vet Entomol. 2012;26:372-8.

210. Bain O, Mutafchiev Y, Junker K, Guerrero R, Martin C, Lefoulon E, et al. Review of the genus Mansonella Faust, 1929 sensu lato (Nematoda: Onchocercidae), with descriptions of a new subgenus and a new subspecies. Zootaxa. 2015;3918:151-93.

211. Verocai GG, Lejeune M, Beckmen KB, Kashivakura CK, Veitch AM, Popko RA, et al. Defining parasite biodiversity at high latitudes of North America: new host and geographic records for Onchocerca cervipedis (Nematoda: Onchocercidae) in moose and caribou. Parasit Vectors. 2012;5:242

212. Lia RP, Mutafchiev Y, Veneziano V, Giannelli A, Abramo F, Santoro M, et al. Filarial infection caused by Onchocerca boehmi (Supperer, 1953) in a horse from Italy. Parasitol Res. 2017;116:191-8.

213. Krueger A, Fischer P, Morales-Hojas R. Molecular phylogeny of the filaria genus Onchocerca with special emphasis on Afrotropical human and bovine parasites. Acta Trop. 2007;101:1-4.

214. Plenge-Bönig A, Krömer M, Büttner DW. Light and electron microscopy studies on Onchocerca jakutensis and O. flexuosa of red deer show different host-parasite interactions. Parasitol Res. 1995:81:66-73.

215. Marini RP, Wachtman LM, Tardif SD, Mansfield K, Fox JG. The common marmoset in captivity and biomedical research. New York: Academic Press; 2018.

216. Strait K, Else JG, Eberhard ML. Parasitic diseases of nonhuman primates. In: Nonhuman primates in biomedical research. Academic Press; 2012. p. 197-297.

217. Lefoulon E, Bain O, Bourret J, Junker K, Guerrero R, Canizales I, et al. Shaking the tree: multi-locus sequence typing usurps current onchocercid (filarial nematode) phylogeny. PLoS Negl Trop Dis. 2015;9:e0004233.

218. Nazni WA, Hoffmann AA, NoorAfizah A, Cheong YL, Mancini MV, Golding $\mathrm{N}$, et al. Establishment of Wolbachia strain wAlbB in Malaysian populations of Aedes aegypti for dengue control. Curr Biol. 2019;29:4241-8.

219. Zélé F, Nicot A, Berthomieu A, Weill M, Duron O, Rivero A. Wolbachia increases susceptibility to Plasmodium infection in a natural system. Proc R Soc B Biol Sci. 2014;281:20132837.

220. de Almeida F, Moura AS, Cardoso AF, Winter CE, Bijovsky AT, Suesdek L. Effects of Wolbachia on fitness of Culex quinquefasciatus (Diptera; Culicidae). Infect Genet Evol. 2011;11:2138-43.

221. Brenner DJ, Krieg NR, Staley JT, editors. Bergey's Manual ${ }^{\circledR}$ of Systematic Bacteriology: Volume Two The Proteobacteria Part C The Alpha-, Beta-, Delta-, and Epsilonproteobacteria. Bergey's Manual Trust; 2005.

\section{Publisher's Note}

Springer Nature remains neutral with regard to jurisdictional claims in published maps and institutional affiliations. 